\title{
Peroxisome Proliferator-Activated Receptors (PPARs) and Oxidative Stress in Physiological Conditions and in Cancer
}

\author{
Giuliana Muzio*D, Giuseppina Barrera and Stefania Pizzimenti $(\mathbb{D}$ \\ Department of Clinical and Biological Sciences, University of Turin, Corso Raffaello 30, 10125 Turin, Italy; \\ giuseppina.barrera@unito.it (G.B.); stefania.pizzimenti@unito.it (S.P.) \\ * Correspondence: giuliana.muzio@unito.it; Tel.: +39-011-6707750
}

Citation: Muzio, G.; Barrera, G.;

Pizzimenti, S. Peroxisome

Proliferator-Activated Receptors (PPARs) and Oxidative Stress in Physiological Conditions and in Cancer. Antioxidants 2021, 10, 1734. https://doi.org/10.3390/ antiox10111734

Academic Editor: Stanley Omaye

Received: 5 October 2021

Accepted: 26 October 2021

Published: 29 October 2021

Publisher's Note: MDPI stays neutral with regard to jurisdictional claims in published maps and institutional affiliations.

Copyright: (c) 2021 by the authors. Licensee MDPI, Basel, Switzerland. This article is an open access article distributed under the terms and conditions of the Creative Commons Attribution (CC BY) license (https:// creativecommons.org/licenses/by/ $4.0 /)$.

\begin{abstract}
Peroxisome proliferator-activated receptors (PPARs) belong to the nuclear hormone receptor superfamily. Originally described as "orphan nuclear receptors", they can bind both natural and synthetic ligands acting as agonists or antagonists. In humans three subtypes, PPAR $\alpha, \beta / \delta$, $\gamma$, are encoded by different genes, show tissue-specific expression patterns, and contribute to the regulation of lipid and carbohydrate metabolisms, of different cell functions, including proliferation, death, differentiation, and of processes, as inflammation, angiogenesis, immune response. The PPAR ability in increasing the expression of various antioxidant genes and decreasing the synthesis of pro-inflammatory mediators, makes them be considered among the most important regulators of the cellular response to oxidative stress conditions. Based on the multiplicity of physiological effects, PPAR involvement in cancer development and progression has attracted great scientific interest with the aim to describe changes occurring in their expression in cancer cells, and to investigate the correlation with some characteristics of cancer phenotype, including increased proliferation, decreased susceptibility to apoptosis, malignancy degree and onset of resistance to anticancer drugs. This review focuses on mechanisms underlying the antioxidant and anti-inflammatory properties of PPARs in physiological conditions, and on the reported beneficial effects of PPAR activation in cancer.
\end{abstract}

Keywords: peroxisome proliferator-activated receptors (PPARs); oxidative stress; cancer; inflammation

\section{Introduction}

The maintenance of intracellular redox homeostasis is crucial to ensure functionality and survival of normal cells. Antioxidant defenses include several enzymes and molecules responsible for the cellular response to oxidative stress. The expression of several of these molecules is directly or indirectly regulated by transcription factors, including Peroxisome Proliferator-Activated Receptors (PPARs). In this view, PPAR antioxidant properties have been deeply investigated in both physiological and pathological conditions. This review focuses on the mechanisms regulating PPAR expression and activity in normal cells, paying particular attention on their involvement in controlling oxidative stress and inflammation. Moreover, knowledge on the effects of PPAR-mediated modulation of oxidative stress in cancer development and progression is also summarized.

\section{PPAR Physiology}

PPARs belong to nuclear hormone receptor superfamily and share characteristic functional domains with other superfamily members. Originally described as "orphan nuclear receptors", PPARs are now known to bind a multitude of both natural and synthetic ligands acting as agonists, antagonists, or inverse agonists [1-4]. Since several of these ligands share the ability to induce, with different entity, peroxisome proliferation in rodent hepatocytes, their receptors have been indicated as PPARs.

In humans three different subtypes, $\operatorname{PPAR} \alpha, \beta / \delta, \gamma$, are encoded by separate genes and show tissue-specific expression patterns [5]. From $P P A R \gamma$ gene three different mRNA 
are transcribed $(\gamma 1, \gamma 2, \gamma 3)$ leading to the production of two proteins. All subtypes are involved in the regulation of lipid and carbohydrate metabolisms (Table 1); moreover, based on their expression in specific cell types or tissues, PPARs can play a pivotal role in modulating different cell functions (proliferation, death, differentiation) [6], inflammatory process [7], angiogenesis [8], immune response [9].

Table 1. Tissue distribution and functions of peroxisome proliferator-activated receptors (PPARs) in lipid and carbohydrate metabolisms.

\begin{tabular}{|c|c|c|}
\hline \multirow{4}{*}{$\begin{array}{l}\text { PPAR } \alpha \\
\text { Refs. [10-12] }\end{array}$} & liver & $\begin{array}{l}\uparrow \text { Oxidation of fatty acids, } \\
\text { ketogenesis, lipid homeostasis }\end{array}$ \\
\hline & heart & $\begin{array}{l}\uparrow \text { Oxidation of fatty acids } \\
\downarrow \text { Glucose uptake }\end{array}$ \\
\hline & kidney & $\uparrow$ Oxidation of fatty acids \\
\hline & brown adipose tissue & $\uparrow$ Oxidation of fatty acids \\
\hline $\begin{array}{l}\text { PPAR } \beta / \delta \\
\text { Refs. }[11,12]\end{array}$ & ubiquitous & $\begin{array}{l}\uparrow \text { Oxidation of fatty acids }+ \\
\text { branched-chain amino acid }\end{array}$ \\
\hline \multirow{3}{*}{$\begin{array}{l}\text { PPAR } \gamma \\
\text { Refs. }[11,13]\end{array}$} & $\begin{array}{l}\text { white adipose tissue } \\
\text { brown adipose tissue }\end{array}$ & $\begin{array}{l}\uparrow \text { Adipogenesis, glucose } \\
\text { homeostasis }\end{array}$ \\
\hline & immune cells & $\begin{array}{l}\uparrow \text { Antigen uptake and } \\
\text { activation, lipid metabolism, } \\
\text { insulin sensitization }\end{array}$ \\
\hline & skeletal muscle & $\uparrow$ Insulin sensitization \\
\hline
\end{tabular}

The ligand-dependent biological effects of PPARs require their heterodimerization with the nuclear receptor Retinoid X Receptor (RXR) and a conformational change that determines co-repressor release and co-activator recruitment. In this activated form, the heterodimer PPAR/RXR binds to protein complexes, including histone acetyltransferase, and to RNA polymerase II, this allowing chromatin remodeling, recruitment of transcription machinery and transcription of target genes (trans-activation action) [14].

In these genes, the DNA-binding sequence of PPAR/RXR complex is called Peroxisome Proliferator Response Elements (PPRE) and consists of a direct repeat (DR-1) motif composed of two half-sites that occur as a direct repetition of a hexanucleotide DNA sequence (AGGTCA) with a single nucleotide spacing between the two repeats. PPRE can be located within promoter, or introns/exons or in $3^{\prime}$ downstream region of target genes [15].

The expression of PPARs has been recently evidenced to be epigenetically modulated by a large number of miRNAs that target the different isoforms. This type of posttranscriptional regulation has been characterized in different diseases in which the expression of specific miRNA contributes to the pathogenesis, mainly through the downregulation of PPARs [16-18]. In a recent review, Sundrani et al. [19] suggested that fatty acid-mediated alterations in miRNAs/PPARs axis could be responsible for placental disorders leading to babies with low birth weight. In a rat model of intestinal injury after hypoxia/reoxygenation, the increased expression of miR-23a-5p has been reported to further worsen cell damage by decreasing PPAR $\alpha$ and its antioxidant effect, this leading to an increased ROS production [20].

The ability of miRNAs in modulating PPAR expression has also been evidenced for the miRNAs delivered in the exosomes. In fact, miR-130a-3p, present in acinar cell-derived exosomes, has been demonstrated to contribute to pancreatic fibrosis onset by decreasing the PPAR $\gamma$ activity in stellate cells by directly binding to the PPAR-3'UTR [21]. miRNAs targeting both PPAR $\gamma$ and $\delta$ have been found to be hyper-expressed in macrophages isolated from visceral adipose tissues of obese mouse and contribute to the induction of insulin-resistance $[22,23]$.

Other than in a direct way, miRNAs can also indirectly affect the PPAR expression/functions since several complexes regulating PPAR transcriptional activity ( co-activators and co-repressors) are in turn targeted by specific miRNAs [24-26]. 
The importance of the axis miRNAs/PPARs in modulating different cell functions was further confirmed by the observation that PPRE sequences are present in the promoter of several miRNAs to indicate a mutual modulation [16].

As previously reported, the activity of PPARs is regulated at different levels: by several molecules or multiprotein complexes that can act as co-activators or co-repressors, and by different types of post-translational modifications.

PPAR co-activators are known to show different intrinsic biological activities. They include: (1) some enzymes, as histone acetylases (CBP/p300 and steroid receptor coactivator, SRC-1) and ATPases (Brg1 or Brm members of SWI/SNF complex), responsible for chromatin remodelling; (2) proteins forming a bridge between the nuclear receptor and the transcription initiation machinery (PPAR binding protein/thyroid receptor associated protein 220, PBP/TRAP220) [27-30].

Peroxisome proliferator-activated receptor gamma co-activator 1 alpha (PGC-1), originally identified as a specific co-activator of PPAR $\gamma$ and now known to modulate the activity of several transcription factors, favours PPAR/RXR action recruiting other co-activators provided with histone acetyltransferase activity, and induces RNA polymerase II action directly interacting with the TRAP/DRIP [31-34].

PPARs can heterodimer with RXR also in the absence of ligands and in this form the dimer remains tied to the co-repressor complexes, such as NCoR (Nuclear receptor corepressor), SMRT (Silencing mediator of retinoid and thyroid hormone receptor) or RIP140 (Receptor Interacting Protein 140). These complexes directly or indirectly recruit histone deacetylases (HDACs) that repress gene transcription via modulation of chromatin structure [35-37].

PPAR activity is also modulated by different types of post-translational modifications, named PTM, that include phosphorylation, SUMOylation, ubiquitination and acetylation. The studies examining this aspect of PPAR physiology have been mostly conducted on PPAR $\alpha$ and $\gamma$. This type of regulation is very articulated, since the PTM effects on PPAR activity depend on various factors, as the PPAR isoform, the site of modifications, the effector of PTM and the substrate availability.

The phosphorylation of PPAR $\alpha$ and $\gamma$ occurs at specific serine residues and can be due to MAPK, CDK or GSK $\beta$. PPAR $\alpha$ phosphorylation in serine 12 and 21 by MAPK or CDK7 is known to increase its activity possibly via improved recruitment of co-activators and release of co-repressors; differently, the degradation of PPAR $\alpha$ is favoured by GSK $\beta$ mediated phosphorylation at serine 73 [38]. With regard to PPAR $\gamma$, the phosphorylation of serine 112 determines a different effect (activation or repression) depending on the kinase involved: the activity is increased in case of MAPK-mediated phosphorylation, whereas is reduced in case of CDK7/9 involvement [39-42].

SUMOylation negatively regulates both PPAR $\alpha$ and $\gamma$ [43-45]. SUMOylation of lysine 185 or 358 in PPAR $\alpha$ decreases its activity in hepatic cell lines and in liver, mainly through an increased binding to NCoR co-repressor [46,47]. In PPAR $\gamma$, several putative SUMOylation sites have been identified [48], but mainly the effects on serine 107 have been extensively investigated $[39,49]$. The importance of PTM in regulating PPAR $\gamma$ activity has been further confirmed by the observation that the phosphorylation at serine 112 seems to favour the SUMOylation at lysine $107[49,50]$, suggesting a possible interconnection among the different PTM pathways.

Polyubiquitination of all PPAR isoforms causes a decrease of transcriptional activity due to their proteasomal degradation [51-54].

\section{PPARs, Inflammation and Oxidative Stress}

All PPAR isoforms hare well known to possess anti-inflammatory activity that takes place through different mechanisms that are summarized in the Table 2.

The ability of PPARs in decreasing the synthesis of pro-inflammatory mediators in several pathological conditions and in inflammatory experimental models has been partially attributed to the ligand-dependent [trans-repression of transcription factors, 
mainly NF-kB, AP-1 and STAT. NF- $\mathrm{kB}$ transcriptional activity is inhibited by a direct interaction of all PPAR isoforms to its p65 component [55-58]. Other than by binding to the ligands, the PPAR-p65 interaction seems to be also modulated by MAPK signalling since ciglitazone induces MAP kinase-mediated phosphorylation of PPAR $\gamma$, this leading to a major inhibition of NF-kB [55].

PPAR $\alpha$ ligands, fibrates and WY-14643, have been evidenced to further decrease NF-kB pathway via modulation of the expression, stability or activity of the inhibitor IkB- $\alpha,[56,59,60]$.

Table 2. Principal mechanisms responsible for the anti-inflammatory activity of PPARs.

\begin{tabular}{|c|c|c|c|c|}
\hline Mechanism & & Characteristics/Effects & Isoform & References \\
\hline $\begin{array}{l}\text { Ligand-dependent } \\
\text { trans-repression activity }\end{array}$ & & $\begin{array}{l}\text { independent from the binding to specific DNA } \\
\text { sequences } \\
\text { based on the interaction between ligand-bound ppar } \\
\text { and components of other transcription factors (NFKB, } \\
\text { AP-1) or regulatory complexes (iNOS) } \\
\text { based on the inhibition of kinases involved in the } \\
\text { activation of other transcription factors }\end{array}$ & $\alpha, \beta / \delta, \gamma$ & [61-68] \\
\hline $\begin{array}{l}\text { Modulation of inflammasoma } \\
\text { activity }\end{array}$ & & $\begin{array}{l}\text { decreased expression of NLRP3, CASPASE 1, IL-1 } \beta \text {, } \\
\text { IL-18 } \\
\text { decreased expression of TLR }\end{array}$ & $\alpha, \beta / \delta, \gamma$ & $\begin{array}{l}{[69,70]} \\
{[71,72]}\end{array}$ \\
\hline $\begin{array}{l}\text { Modulation of } \\
\text { pro-inflammatory genes }\end{array}$ & & $\begin{array}{l}\text { increased expression of anti-inflammatory miRNA } \\
\text { (miR-142-3p, miR-124) }\end{array}$ & $\gamma$ & {$[73,74]$} \\
\hline $\begin{array}{l}\text { Direct up-regulation of genes } \\
\text { with anti-inflammatory } \\
\text { properties. }\end{array}$ & & $\begin{array}{l}\text { increased expression via binding to ppre in target } \\
\text { genes (HO-1, C3, PGlyRPs, IL-10, eNOS, UCP2) }\end{array}$ & $\alpha$ & {$[75-78]$} \\
\hline crosstalk with NRF2 & & $\begin{array}{l}\text { "ARE" Sequences Present in PPAR } \gamma \text { promoter } \\
\text { putative PPRE sequences IN Nrf2 gene }\end{array}$ & $\gamma$ & $\begin{array}{c}{[79,80]} \\
{[81]}\end{array}$ \\
\hline
\end{tabular}

A direct protein-protein interaction is also responsible for the trans-repression of AP-1 activity; in fact, GST pull-down experiments carried out by Delerive et al. [81] evidenced a binding of PPAR $\alpha$ to the amino-termi nal domain of c-Jun.

The transcription of STAT5 target genes has been reported to be inhibited in a dosedependent way by PPAR $\alpha$ and $\gamma$ activation [82]. This observation evidenced a reciprocal negative regulation between PPAR and STAT pathways, since it was previously demonstrated that STAT5b inhibits PPAR transcriptional activity by binding to ligandindependent AF-1 domain in PPARs [83,84]. The lack of STAT5b inhibition evidenced in case of PPAR $\alpha$ lacking AF-1 confirmed the importance of this domain in STAT5b-PPAR crosstalk. The ability of PPARs in reducing STAT pathway has also been confirmed by the finding that in human macrophages PPAR $\alpha$ and $\gamma$ agonists decreased STAT-mediated transactivation without directly decreasing the DNA binding of these transcription factors [85].

More recently, the treatment with HuoXueTongFu Formula, a liquid herbal formula used in traditional chinese medicine and possessing anti-inflammatory properties, has been shown to prevent intraperitoneal adhesion occurring after abdominal surgery by modulating cytokine production via PPAR $\gamma$-mediated downregulation of SOCS3/JAK2/STAT1 pathway [86].

Over the past 20 years, the ability of PPARs in modulating inflammasome activity was included among the mechanisms responsible for their anti-inflammatory properties. In particular, the majority of the studies investigated PPARs as regulators of NLRP3, the most studied inflammasome complex [74].

PPAR $\gamma$ activation via both natural and synthetic ligands, $\omega-3$ polyunsaturated fatty acids, (PUFA) and rosiglitazone, have been demonstrated to inhibit NLRP3 increased transcription occurring in mice deficient for CGI-58, a co-activator of adipose triglyceride lipase, administered with a lipid rich diet, and in LPS-treated murine Raw 264.7 cells $[68,87]$. The beneficial effect of Morin (3,5,7,2', $4^{\prime}$-pentahydroxyflavone), a natural flavonoid, on 
obesity induced by high-fat diet in rats has been ascribed to its binding to PPAR $\alpha$ and the consequent decrease of mRNA of the NLRP3 inflammasome complex that is overexpressed in this pathological condition. Moreover, the PPAR $\alpha$ activation positively affects fatty acid catabolism improving lipid profile in liver. A similar effect, albeit to a lesser extent, has been observed in the same experimental model after treatment with a mixture of EPA and DHA (eicosapentaenoic and docosaexaenoic acid, respectively) [88]

The efficacy of rosiglitazone in reducing inflammation via modulation of NLRP3 has been more recently confirmed in a model of radiation-induced acute intestinal injury and in intestinal macrophages isolated from the same animals [69].

In a similar way, the anti-inflammatory activity showed by abscisic acid, a natural phytohormone, in a murine model of allergic airway inflammation has been attributed to its ability in increasing PPAR $\gamma$ expression and, in consequence, in inhibiting NLRP3 [89]. In a mouse model of NAFLD (Nonalcoholic fatty liver disease), GW501516, a specific PPAR $\beta$ / $\delta$ ligand, inhibited the activation of NLRP3, NLRP6, and NLRP10 and decreased the production of pro-inflammatory molecules induced by high fat diet and LPS [90].

At the present, two mechanisms have been suggested as responsible for the PPAR $\gamma$ mediated modulation of inflammasome activity: a downregulation of the expression of inflammasome components and a direct interaction between DBD domain of PPAR and NLRP3, this interfering with NLRP3 assembly [69,91].

The crosstalk between PPARs and Nrf2 (NF-E2-related factor 2), has been evidenced to play an important role not only in modulating inflammatory process, but also oxidative stress. Nrf2 is considered as one of the most important regulator of cellular response to oxidative stress [92-94] and of xenobiotic metabolism, via binding to Antioxidant Response Element (ARE) in the promoter of target genes. The anti-inflammatory action of Nrf2 is mainly due to its ability in modulating several pathways and determining: (1) inhibition of NF-kB transcriptional activity via competition with co-activator CBP [95-97]; (2) inhibition of the expression of cytokines TNF $\alpha$, IL-6, IL-1 $\beta$, and of COX and iNoS [98-100].

The involvement of both Nrf2 and PPARs in modulating inflammatory process suggested the possibility of a mutual control of the expression of these transcription factors. This hypothesis has been directly confirmed by the observations that two ARE are present in PPAR $\gamma$ promoter [78,79] and a putative PPRE is present in Nrf2 promoter region [101]. Based on these observations several studies investigated the possibility to improve the regulation of inflammation process by acting simultaneously on PPAR and Nrf2 pathways. With this aim, the effects of specific Nrf2 or PPAR activators, or dual agonists have been investigated in both in vivo and in vitro models of different diseases characterized by increased inflammation and oxidative stress. The results evidenced, in most cases, greater beneficial outcomes and confirmed the significant crosstalk between PPARs and Nrf2 [102-104]. This last aspect has been further underlined by the observation that the promoter of some genes, as glutathione transferase, contains both ARE and PPRE sequences [101].

PPAR anti-inflammatory properties also contribute, in an indirect way, to their ability in acting as regulator of cellular response to oxidative stress. As a whole, the antioxidant activity of PPARs is mainly due to their ability in directly activating the transcription of genes showing antioxidant activity, in modulating at post-transcriptional level the activity of proteins with antioxidant functions, or negatively affecting the expression/activity of proteins generating or metabolizing free radicals.

Table 3 summarises genes containing PPRE in their promoter region, as evidenced by bioinformatic approach or reporter gene assay. 
Table 3. Main antioxidant genes under transcriptional control of PPARs.

\begin{tabular}{|l|l|l|l|}
\hline \multicolumn{1}{|c|}{ Gene } & \multicolumn{1}{|c|}{ Function } & \multicolumn{1}{c|}{ Spefies } & \multicolumn{1}{c|}{ [105-107] } \\
\hline Catalase & Decomposition of $\mathrm{H}_{2} \mathrm{O}_{2}$ & Human, mouse, rat & {$[108,109]$} \\
\hline Heme Oxygenase-1 & $\begin{array}{l}\text { Induction of DNA binding activities of transcription } \\
\text { factors involved in response to oxidative stress. }\end{array}$ & Mouse & [110] \\
\hline Glutathione Peroxidase 3 & $\begin{array}{l}\text { Reduction of hydrogen peroxide and related lipid } \\
\text { hydroperoxides. }\end{array}$ & Human & [111] \\
\hline Superoxide Dismutase & $\begin{array}{l}\text { Conversion of two superoxide anions to oxygen and } \\
\text { hydrogen peroxide }\end{array}$ & Mouse \\
\hline Thioredoxin & $\begin{array}{l}\text { Redox active protein containing two cysteine } \\
\text { residues }\end{array}$ & Human & Human \\
\hline CD36 & Scavenger receptor for oxidized lipids & Rat & {$[1113]$} \\
\hline Uncoupling Protein & $\begin{array}{l}\text { Modulation of free radical production in } \\
\text { mitochondria }\end{array}$ & {$[116]$} \\
\hline
\end{tabular}

The presence of the PPAR DNA-binding sequence in genes under transcriptional control of PPARs has been previously suggested by studies using specific ligands for the different PPAR isoforms, knockout animals or silencing technique.

The researches on this topic deeply investigated the correlation between PPAR $\gamma$ and catalase expression, evidencing that this isoform prevents, via catalase induction, the oxidative stress associated with different conditions, as apoptosis induction [117], pesticide inhalation [118], LPS-induced brain impairment [119], hypertension [120], calcium oxalate-induced nephrolithiasis [114]. This antioxidant effect has been observed using canonical synthetic PPAR $\gamma$ agonists (pioglitazone, rosiglitazone) [119,121], natural ligands, as catalpol [122] or a combination of synthetic and natural ones (carvacrol plus pioglitazone [118].

In a similar way, PPAR $\alpha$ agonist fenofibrate has been recently reported to reduce oxidative stress through the increased expression of catalase in cultured rat cardiomiocytes exposed to high glucose uptake or hypoxia/reperfusion condition [123]. The fenofibratemediated increase of catalase expression, and the consequent improvement of redox state, also occurred in testicular tissue of diabetic rats [124].

$\operatorname{PPAR} \beta / \delta$ has been evidenced to play a crucial role in maintaining function and characteristics of vascular endothelium in in vivo and in vitro studies through its ability in modulating the expression of antioxidant enzymes, including catalase.

In a rat model of ischemia/reperfusion PPAR $\beta / \delta$ activation with the specific ligand GW0742 upregulated catalase, UCP-3 and superoxide dismutase 2 (SOD2) [125]. The consequent reduction of oxidative stress has been demonstrated by the decreased production of 4-hydroxy-2-nonenal (HNE), the major lipid peroxidation product, and of formation of its adducts with proteins. Interestingly, this research also evidenced that PPAR $\beta / \delta$ increased at transcription level the expression of aldehyde dehydrogenase 2 (ALDH2), the mitochondrial isoenzyme of ALDH known to metabolize acetaldehyde and HNE derived from lipid peroxidation [126,127]. This observation indicates that PPAR modulation of oxidative stress is also due to their ability in favouring the metabolism of highly reactive aldehydic products of lipid peroxidation.

As in the case of catalase, also SOD expression is directly increased by ligands of all PPAR isoforms. This contributes to the beneficial effects of these molecules reported in different pathological conditions characterized by oxidative stress, including oxidative damage of pancreatic cells and atrial remodelling in diabetes [128,129], intervertebral disc degeneration responsible for of back and neck pain [130], benign prostatic hyperplasia [131].

An important crosstalk involved in intracellular defence against oxidative and inflammatory conditions concerns PPARs and heme oxygenase (HO), mainly HO-1. All PPAR isoforms have been reported to induce the expression of HO-1 [132]. PPAR-mediated expression of HO-1 contributes in preserving/improving vascular integrity in different conditions of vascular disorders, as angiotensin II-induced hypertension in rats $[133,134]$ and pulmonary hypertension due to proliferation of smooth muscle cells [135]. In iron- 
challenged hepatocytes, the adiponectin-mediated activation of axis PPAR/HO-1 decreases apoptotic cell death and iron accumulation, reducing the clinical hepatic consequence of iron overload [136]. A similar protective effect due to PPAR $\gamma$ and HO-1 overexpression/activation has been described in an animal models of fibrotic steatohepatitis [137] and in renal damage consequent to ischemia / reperfusion [138]. The ability of HO in influencing in turn PPAR activity has been documented by the observation that in macrophages and muscle cells carbon monoxide produced by HO- 1 activity is able to increase PPAR $\gamma$ and $\beta / \delta$, this leading to beneficial effect through the modulation of different signalling transduction pathways, including inhibition of early growth response-1 (Egr-1) and activation of ERK5 [139-142].

Uncoupling proteins (UCPs) contribute to the maintenance of intracellular redox homeostasis by decreasing the ROS production in mitochondria [143]. In this view, the regulation at transcriptional level of their expression by PPARs represents an important mechanism contributing to cellular defence toward oxidative stress. The first studies on this aspect of PPAR antioxidant activity mainly investigated the effect of PPAR $\alpha$ and $\gamma$ ligands on the expression and activity of the three UCP isoforms. Teruel's group evidenced that in rat brown adipocytes rosiglitazone increased UCP-3 and UCP-1, and WY14643 increased UCP-3, also suggesting a possible synergic or competitive effect of contemporary administration of both ligands depending on the specific UCP isoform $[114,115,144]$. Transcriptional upregulation of UCP-2 induced by rosiglitazone protects against oxidative stress in rostral ventrolateral medulla, preserving the activity of premotor neurons responsible for the maintenance of neurogenic vasomotor tone, and reducing hypertension [145]. More recently, PPAR $\beta / \delta$ specific ligand GW0742 has been shown to relieve endothelial alterations induced by LPS via upregulation of UCP-2 and the consequent reduction of intra-mitochondrial ROS production [146].

\section{PPARs and Oxidative Stress in Cancer}

Based on the multiplicity of physiological effects above-described, PPAR involvement in cancer development and progression has attracted great scientific interest.

The main observation emerged from the studies is that a wide species specificity characterizes the effects of the activation of different PPAR isoforms on carcinogenesis process.

The species specificity of PPAR effects has been above all documented for PPAR $\alpha$ whose activation, by natural or synthetic ligands, resulted associated with hepatocarcinoma occurrence in rodents, and not in other species. In sensitive species, PPAR $\alpha$ activation seems to drive liver carcinogenesis through several mechanisms, including increase of cell proliferation via activation of c-Myc and cyclins, decrease of susceptibility to undergo apoptosis, increase of oxidative stress [147-149]. This last event seems to be triggered by the PPAR $\alpha$-mediated increase of enzymes showing oxidase activity and different subcellular localisation, as in peroxisome, endoplamatic reticulum, and mitochondria.

In particular, acyl-CoA oxidase (ACO) [150], NADPH oxidase [151,152] and cytochrome P4504A1 [153] have been indicated as responsible for the increased ROS production contributing to the initiation phase of carcinogenic process in murine liver. In the same animals, a PPAR $\alpha$-mediated energy burning in liver has been also indicated as a factor contributing to hepatocarcinogenesis [154].

In the various species, the different ability of PPAR $\alpha$ ligands in inducing ROS formation has been related with a different basal expression level present in the hepatocytes. In particular, in human liver, a low level of PPAR $\alpha$ mRNA and protein has been reported [155], even if this observation has not been confirmed in a study comparing the consequences of PPAR $\alpha$ activation in cultured human and rodent hepatocytes, and suggesting a major effect of PPAR $\alpha$ [156]. Other than to the low expression level, a different sequence in ligand-binding domain (LBD) of PPAR $\alpha$ could decrease the response to the same ligand concentrations in primates and humans and, in consequence, their susceptibility to undergo carcinogenesis process. 
With regard to the changes occurring in cancers and cultured cancer cells, both increase or decrease of PPAR expression have been reported (Table 4). Anyway, the alterations in the activity of these nuclear receptors always significant contribute to the acquisition of cancer phenotype.

Table 4. PPAR expression in some cancers in comparison with corresponding normal cells/tissues.

\begin{tabular}{|c|c|c|c|}
\hline PPAR Isoform & Cancer Type & Change in the Expression & References \\
\hline \multirow[t]{7}{*}{$\gamma$} & $\begin{array}{l}\text { Colorectal Carcinoma } \\
\text { (human specimens) }\end{array}$ & Decrease & {$[157,158]$} \\
\hline & $\begin{array}{l}\text { Gastric Carcinoma } \\
\text { (human specimens) }\end{array}$ & Decrease & [159] \\
\hline & $\begin{array}{l}\text { Nonmedullary Thyroid Carcinoma } \\
\text { (human specimens) }\end{array}$ & Decrease & [160] \\
\hline & $\begin{array}{l}\text { Cervical Carcinoma } \\
\text { (human specimens) }\end{array}$ & Decrease & [161] \\
\hline & $\begin{array}{l}\text { Esophageal Cancer } \\
+(\text { human specimens) }\end{array}$ & Decrease & [162] \\
\hline & $\begin{array}{l}\text { Prostate Carcinoma } \\
\text { (human specimens) }\end{array}$ & Increase & [163] \\
\hline & $\begin{array}{l}\text { Colorectal Carcinoma } \\
\text { (human specimens) }\end{array}$ & Decrease & [164] \\
\hline \multirow[t]{3}{*}{$\alpha$} & $\begin{array}{l}\text { Colorectal Carcinoma } \\
\text { (CaCo-2 cells) }\end{array}$ & Increase & [165] \\
\hline & $\begin{array}{l}\text { Ampullary Cancer } \\
\text { (human specimens) }\end{array}$ & Increase & [166] \\
\hline & Lung Cancer(mouse model) & Decrease & [167] \\
\hline \multirow[t]{6}{*}{$\beta / \delta$} & $\begin{array}{c}\begin{array}{c}\text { Prostate Carcinoma } \\
\text { (human specimens; }\end{array} \\
\text { DU145, PC3, LNCAP, VCAP, C4-2, 22RV1 cell lines) }\end{array}$ & Decrease & [168] \\
\hline & $\begin{array}{c}\text { Melanoma } \\
\text { (human specimens; A375 cell line) }\end{array}$ & Increase & [169] \\
\hline & $\begin{array}{c}\text { NSCLC } \\
\text { (human specimens; H358, H441, H23, A549 cell lines) }\end{array}$ & Increase & [170] \\
\hline & $\begin{array}{c}\text { Thyroid Cancer } \\
\text { (human specimens) }\end{array}$ & Increase & [171] \\
\hline & $\begin{array}{l}\text { Ovarian Cancer } \\
\text { (mouse model) }\end{array}$ & Increase & [172] \\
\hline & $\begin{array}{l}\text { Colorectal Carcinoma } \\
\text { (human specimens) }\end{array}$ & Increase & [164] \\
\hline
\end{tabular}

The different trend in PPAR expression evidenced in various types of tumours could be related to the activity levels present in the corresponding normal cells or to the tissuespecific functions played by each isoform. Interestingly, a correlation between PPAR expression and malignancy degree have been observed in some tumours, this further underlying the pivotal role played by PPARs also in cancer progression and suggesting the possibility to different affect cancer cells with different malignancy degree using PPAR ligands [163].

In this view, conjugated linoleic acid (CLA) has been shown to be more effective against cancer cells with higher malignancy degree and originated from different tissues. Moreover, the kind of effect was dependent on the different modulation of PPAR isoforms. In fact, the contemporary increase of PPAR $\alpha$ and decrease of PPAR $\beta / \delta$ was associated with the induction of apoptotic death, whereas PPAR $\gamma$ activation with the inhibition of cell proliferation [63]. These results have been confirmed in human hepatocarcinoma HepG2 cells where the specific PPAR $\alpha$ agonist clofibrate caused apoptosis in a time- and concentrationdependent way, and PGJ2, a ligand of PPAR $\gamma$, inhibited cell proliferation [173]. In rat hepatoma cell lines exposed to high clofibrate concentrations capable of also activating $\operatorname{PPAR} \gamma$, the inhibition of proliferation was mediated by the increase of protein phosphatase $2 \mathrm{~A}$ and the consequent decrease of Erk1,2 and c-myc [174]. The increased expression of PP2A has been later attributed to the presence of putative PPRE sequences in genes 
encoding its subunits [175]. In human hepatocellular carcinoma HepG2 and in colorectal adenocarcinoma $\mathrm{CaCO} 2$ cells, the concurrent administration of PPAR $\alpha$ ligand clofibrate and of JNK inhibitor AS60012145 reduced proliferation and induced apoptosis, likely via the overexpression of 28 genes containing PPRE [176]. PPAR ligands have been shown to reduce cancer cell growth also acting synergistically with HNE [177,178].

The anticancer effect of PPARs is also due to their ability in modulating oxidative stress, through the effect on the expression of antioxidant enzymes, the induction of lipid peroxidation and the activity of enzymes metabolizing the lipid peroxidation products.

These effects have been observed using both natural or synthetic ligands of the different isoforms.

With regard to the involvement of PPAR activation in early stages of carcinogenesis process, the beneficial reported effects can be mainly referred to the prevention of oxidative stress associated with tumoral cell transformation.

In animal experimental models of lung cancer, oral administration of rosiglitazone resulted in an increase of GPx expression and glutathione content, and in a decreased of malondialdeyde (MDA) production, this blocking the diethylnitrosamine-induced cancer formation [179]. In a similar way, Balupillai and coll. [180] demonstrated that the induction of photocarcinogenesis in mice skin was prevented by caffeic acid probably through the activation of PPAR $\gamma$ and the improvement of oxidative imbalance induced by UVB. Lycopene, a natural carotenoid known to prevent the development of several types of cancers, has been shown to activate PPAR $\gamma$ in esophageal cancer cell line EC109, and to inhibit, at appropriate doses, the esophageal carcinogenesis induced by methylbenzylnitrosamine in rat, via the reduction of oxidative stress-mediate MDA formation and of pro-inflammatory cytokine level [181,182].

Studies on cultured tumour cells, derived from different tissues, evidenced that the anticancer effect of PPARs can occur also through the modulation of different signalling pathways and the induction of oxidative stress causing a cytostatic or cytotoxic effect.

Arachidonic acid, a natural ligand of PPARs, caused suppression of growth of lung cancer cells A549, through the increase of PPAR $\gamma$ and lipid peroxidation. In this cells the known cytostatic effect of lipid peroxidation products [183] was augmented by the decreased expression of cytosolic ALDH3, the main responsible for the catabolism of aldehydes derived from PUFA oxidative breakdown. The reduction of ALDH3 expression has been demonstrated to be due to the PPAR-mediated inhibition of NF-kB, for which several consensus sequences are present in the ALDH gene [184].

In lung cancer cells A427, both n-3 and n-6 PUFA increased PPAR $\alpha$ expression and lipid peroxidation, and inhibited cell proliferation [185]. In this research, a putative PPRE has been evidenced in genes encoding the fast isoforms of myosin heavy chain, which suggested the PPAR activation as possible therapeutic approach against cancer cachexia. To be noted that treating cancer cells with PUFA is motivated by the fact that carcinogenetic process is associated with a reduced PUFA amount in membrane phospholipids, this contributing to their decreased susceptibility to undergo lipid peroxidation [186,187].

The cytostatic effect of PPARs has been evidenced also by Srivastava and coll. [188] in lung adenocarcinoma cells NCI-H2347 and NCI-H1993, where an alternative pathway of PPAR-mediated cell growth inhibition has been documented. In fact, in this experimental model, the PPAR $\gamma$ activation by pioglitazione caused a metabolic switch consisting in a decrease of pyruvate oxidation and GSH level. In turn, the decreased intracellular antioxidant defence augmented ROS production determining the hypophosphorylation of retinoblastoma protein and the block of cell cycle.

Using a multi-tiered approach, Savic and coll. [189] confirmed in human colon cancer cells HT-29 that PPAR $\gamma$ activation decreases proliferation through the increase of lipid peroxidation consequent to the GSH reduction.

A mutual influence among PPAR isoforms has been observed in human squamous carcinoma cells SCC-15, where silencing PPAR $\gamma$ caused an increase of PPAR $\alpha$ and $\beta$ mRNA [190]. The authors suggested the possibility that PPAR $\gamma$ negatively regulates the 
expression of other PPARs. This finding could be important in designing new therapeutic approaches aiming to differently affect various PPARs in cancers.

An important event reducing the efficacy of anticancer therapies is the onset of cancer cell resistance to chemotherapeutic drugs, that can be due to several mechanisms, including the increase of antioxidant defences and drug transporter proteins, decrease of detoxifying enzymes or susceptibility to apoptosis.

The above-reported ability of PPARs in modulating ALDH expression, confirmed also in rat hepatoma cells and human breast cancer cells [191,192], can represent a strategy to reduce the resistance to anticancer drugs acting through the formation of free radicals, as doxorubicin, or oxazaphosphorines, whose metabolic intermediates are catabolized by ALDH [193]. It is important underlying that in several type of cancers the expression of ALDH1 and ALDH3 is constitutively increased and contributes to their decreased susceptibility to the effects of lipid peroxidation products. [194].

Superparamagnetic iron oxide nanoparticles (SPIONs) functionalized with CLA for theranostics use, other than to inhibit breast cancer cell growth via PPAR $\gamma$ activation, also decreased the expression of P-glycoprotein, a drug efflux transporter. This effect is probably the consequence of PPAR-mediated induction of necrosis, increase of TNF $\alpha$ and IL-1 $\beta$, cytokines known to inhibit P-glycoprotein expression [192,195].

In gastrointestinal cancer cells, the cisplatin resistance, characterized by increased expression of aldo-keto reductase 1B10 (AKR1B10), an enzyme associated with resistance) against anticancer drugs and decreased PPAR $\gamma$, is reverted by a combined treatment with a AKR1B10 inhibitor and rosiglitazone [196]. The onset of resistance to cisplatin reduces the therapy efficacy also against brain cancers. Human glioma cells U-87 overexpressing PPAR $\gamma$ showed a decreased production of P-glycoprotein, increased oxidative stress and sensitivity to cisplatin in comparison with parenteral ones [197].

The importance of PPARs in preventing the chemoresistance occurrence has been confirmed in non-small cell lung cancers (NSCLC) where hypoxia, via HIF-1, has been evidenced to contribute to the resistance to cisplatin or docetaxel. The mechanisms responsible seems to be the inhibition of PPAR $\gamma$, the decrease of UCP-2, and the consequent ROSinduced expression of ABC transporter protein ABCG2, which causes drug efflux [198].

In the same type of cancer cells, CB13 (1-benzyl-5-(4-methylphenyl) pyrido [2,3d]pyrimidine-2, $4(1 \mathrm{H}, 3 \mathrm{H})$-dione), a recently synthesized PPAR $\gamma$ ligand, reduces the radioresistance via the production of ROS and induced apoptosis through the stimulation of caspase-3, and caspase-9 activities [199].

Since the adaptive increase of antioxidant defences in cancers represents an important factor in inducing chemoresistance, several studies evidenced that a constitutive activation of Nrf2, due to increased expression or mutations in Nrf2 or its inhibitor KEAP1, contributes to the resistance to therapy in various types of cancers [200].

In this view, the above-reported crosstalk between PPARs and Nrf2 could represent an important target to increase cancer sensibility to chemotherapeutics. This possibility has been indirectly investigated by Zhan and coll. [201] in NSCLC cell lines knockdown for KEAP1, the Nrf2 inhibitor. In these cells, the moderate increase of Nrf2 level was associated with the increase of PPAR $\gamma$ and sensibility to cytotoxic effect of arsenic trioxide ( $\operatorname{As}(2) \mathrm{O}(3))$, etoposide, and doxorubicin.

Recently, another beneficial effect of PPAR $\gamma / \mathrm{Nrf} 2$ activation in cancer cells has been reported in a rat model of paclitaxel-induced neuropathic pain Rosiglitazone has been shown to revert the downregulation of PPAR $\gamma$ occurring in the spinal cord of rats showing paclitaxel-induced neuropathic pain, and reduce the pain, probably through the increased expression of Nrf2/HO-1 [103].

\section{Conclusions}

Starting from their classification as members of Nuclear Receptor superfamily, PPARs have been the subject of increasing scientific interest and studies leading to the characterisation of the roles played by the three isoforms in modulating different cell metabolisms and 
functions in normal cells. Based on the multiplicity of their physiological activities, PPARs have been demonstrated to be able to influence the different phases of carcinogenic process and some cancer cell characteristics, including growth, death, invasivity and resistance to anticancer therapy.

The fact that PPAR ligands include a wide variety of natural substances, as dietary fatty acids and natural antioxidants, makes PPAR activation an attractive and more save approach to selectively target cancer cells.

Author Contributions: Conceptualization, G.M., G.B., S.P. All authors have read and agreed to the published version of the manuscript.

Funding: The work was supported by University of Turin (RILO), Italy.

Conflicts of Interest: The authors declare no conflict of interest.

\section{References}

1. Youssef, J.; Badr, M.Z. PPARs: History and advances. Methods Mol. Biol. 2013, 952, 1-6. [CrossRef] [PubMed]

2. Takada, I.; Makishima, M. Peroxisome proliferator-activated receptor agonists and antagonists: A patent review (2014-present). Expert Opin. Ther. Pat. 2020, 30, 1-13. [CrossRef]

3. Peters, J.M.; Gonzalez, F.J.; Müller, R. Establishing the role of PPAR $\beta$ / $\delta$ in carcinogenesis. Trends Endocrinol. Metab. 2015, 26, 595-607. [CrossRef] [PubMed]

4. Heidari, Z.; Chrisman, I.M.; Nemetchek, M.D.; Novick, S.J.; Blayo, A.L.; Patton, T.; Mendes, D.E.; Diaz, P.; Kamenecka, T.M.; Griffin, P.R.; et al. Definition of functionally and structurally distinct repressive states in the nuclear receptor PPAR $\gamma$. Nat. Commun. 2019, 10, 5825. [CrossRef]

5. Dubois, V.; Eeckhoute, J.; Lefebvre, P.; Staels, B. Distinct but complementary contributions of PPAR isotypes to energy homeostasis. J. Clin. Investig. 2017, 127, 1202-1214. [CrossRef]

6. Escher, P.; Wahli, W. Peroxisome proliferator-activated receptors: Insight into multiple cellular functions. Mutat Res. 2000, 448, 121-138. [CrossRef]

7. Alatshan, A.; Benkő, S. Nuclear receptors as multiple regulators of nlrp3 inflammasome function. Front. Immunol. 2021, 12, 630569. [CrossRef]

8. Wagner, N.; Wagner, K.D. PPARs and angiogenesis-implications in pathology. Int. J. Mol. Sci. 2020, 21, 5723. [CrossRef]

9. Christofides, A.; Konstantinidou, E.; Jani, C.; Boussiotis, V.A. The role of peroxisome proliferator-activated receptors (PPAR) in immune responses. Metabolism 2021, 114, 154338. [CrossRef] [PubMed]

10. Desvergne, B.; Wahli, W. Peroxisome proliferator-activated receptors: Nuclear control of metabolism. Endocr. Rev. 1999, 20, 649-688. [CrossRef] [PubMed]

11. Mukherjee, R.; Jow, L.; Croston, G.E.; Paterniti, J.R., Jr. Identification, characterization, and tissue distribution of human peroxisome proliferator-activated receptor (PPAR) isoforms PPARgamma2 versus PPARgamma1 and activation with retinoid $X$ receptor agonists and antagonists. J. Biol. Chem. 1997, 272, 8071-8076. [CrossRef]

12. Auboeuf, D.; Rieusset, J.; Fajas, L.; Vallier, P.; Frering, V.; Riou, J.P.; Staels, B.; Auwerx, J.; Laville, M.; Vidal, H. Tissue distribution and quantification of the expression of mRNAs of peroxisome proliferator-activated receptors and liver $\mathrm{X}$ receptor-alpha in humans: No alteration in adipose tissue of obese and NIDDM patients. Diabetes 1997, 46, 1319-1327. [CrossRef]

13. Vidal-Puig, A.J.; Considine, R.V.; Jimenez-Liñan, M.; Werman, A.; Pories, W.J.; Caro, J.F.; Flier, J.S. Peroxisome proliferatoractivated receptor gene expression in human tissues. Effects of obesity, weight loss, and regulation by insulin and glucocorticoids. J. Clin. Investig. 1997, 99, 2416-2422. [CrossRef]

14. Westin, S.; Kurokawa, R.; Nolte, R.T.; Wisely, G.B.; McInerney, E.M.; Rose, D.W.; Milburn, M.V.; Rosenfeld, M.G.; Glass, C.K. Interactions controlling the assembly of nuclear-receptor heterodimers and co-activators. Nature 1998, 395, 199-202. [CrossRef]

15. Dharap, A.; Pokrzywa, C.; Murali, S.; Kaimal, B.; Vemuganti, R. Mutual induction of transcription factor PPAR $\gamma$ and microRNAs miR-145 and miR-329. J. Neurochem. 2015, 135, 139-146. [CrossRef] [PubMed]

16. Portius, D.; Sobolewski, C.; Foti, M. MicroRNAs-dependent regulation of PPARs in metabolic diseases and cancers. PPAR Res. 2017, 2017, 7058424. [CrossRef] [PubMed]

17. Zhang, S.; Yin, Z.; Dai, F.F.; Wang, H.; Zhou, M.J.; Yang, M.H.; Zhang, S.F.; Fu, Z.F.; Mei, Y.W.; Zang, M.X.; et al. miR-29a attenuates cardiac hypertrophy through inhibition of PPAR expression. J. Cell Physiol. 2019, 234, 13252-13262. [CrossRef]

18. McGregor, R.A.; Choi, M.S. microRNAs in the regulation of adipogenesis and obesity. Curr. Mol. Med. 2011, 11, 304-316. [CrossRef] [PubMed]

19. Sundrani, D.P.; Karkhanis, A.R.; Joshi, S.R. Peroxisome Proliferator-Activated Receptors (PPAR), fatty acids and microRNAs: Implications in women delivering low birth weight babies. Syst. Biol. Reprod. Med. 2021, 67, 24-41. [CrossRef]

20. Li, L.X.; Yin, L.H.; Gao, M.; Xu, L.N.; Qi, Y.; Peng, J.Y. MiR-23a-5p exacerbates intestinal ischemia-reperfusion injury by promoting oxidative stress via targeting PPAR alpha. Biochem. Pharmacol. 2020, 180, 114194. [CrossRef] 
21. Wang, Q.; Wang, H.; Jing, Q.; Yang, Y.; Xue, D.; Hao, C.; Zhang, W. Regulation of pancreatic fibrosis by acinar cell-derived exosomal miR-130a-3p via targeting of stellate cell PPAR- $\gamma$. J. Inflamm. Res. 2021, 14, 461-477. [CrossRef]

22. Ying, W.; Riopel, M.; Bandyopadhyay, G.; Dong, Y.; Birmingham, A.; Seo, J.B.; Ofrecio, J.M.; Wollam, J.; Hernandez-Carretero, A.; $\mathrm{Fu}, \mathrm{W}$; et al. Adipose Tissue Macrophage-Derived Exosomal miRNAs Can Modulate In Vivo and In Vitro Insulin Sensitivity. Cell 2017, 171, 372-384.e12. [CrossRef]

23. Liu, T.; Sun, Y.C.; Cheng, P.; Shao, H.G. Adipose tissue macrophage-derived exosomal miR-29a regulates obesity-associated insulin resistance. Biochem. Biophys. Res. Commun. 2019, 515, 352-358. [CrossRef]

24. Zhou, R.; Li, X.; Hu, G.; Gong, A.Y.; Drescher, K.M.; Chen, X.M. miR-16 targets transcriptional corepressor SMRT and modulates NF-kappaB-regulated transactivation of interleukin-8 gene. PLoS ONE 2012, 7, e30772. [CrossRef] [PubMed]

25. Liu, W.; Bi, P.; Shan, T.; Yang, X.; Yin, H.; Wang, Y.X.; Liu, N.; Rudnicki, M.A.; Kuang, S. miR-133a regulates adipocyte browning in vivo. PLoS Genet. 2013, 9, e1003626. [CrossRef] [PubMed]

26. Tombolan, L.; Zampini, M.; Casara, S.; Boldrin, E.; Zin, A.; Bisogno, G.; Rosolen, A.; De Pittà, C.; Lanfranchi, G. MicroRNA-27a contributes to rhabdomyosarcoma cell proliferation by suppressing RARA and RXRA. PLoS ONE 2015, 10, e0125171. [CrossRef] [PubMed]

27. Rosenfeld, M.G.; Lunyak, V.V.; Glass, C.K. Sensors and signals: A coactivator/corepressor/epigenetic code for integrating signal-dependent programs of transcriptional response. Genes Dev. 2006, 20, 1405-1428. [CrossRef]

28. Zhu, Y.; Qi, C.; Calandra, C.; Reddy, J.K. Cloning and identification of mouse steroid receptor coactivator-1 (mSRC-1), as a coactivator of peroxisome proliferator-activated receptor gamma. Gene Expr. 1996, 6, 185-195.

29. Zhu, Y.; Qi, C.; Jain, S.; Reddy, J.K. Isolation and characterization of PBP, a protein that interacts with peroxisome proliferatoractivated receptor. J. Biol. Chem. 1997, 272, 25500-25506. [CrossRef] [PubMed]

30. Salma, N.; Xiao, H.; Mueller, E.; Imbalzano, A.N. Temporal recruitment of transcription factors and SWI/SNF chromatinremodeling enzymes during adipogenic induction of the peroxisome proliferator-activated receptor gamma nuclear hormone receptor. Mol. Cell Biol. 2004, 24, 4651-4663. [CrossRef] [PubMed]

31. Wallberg, A.E.; Yamamura, S.; Malik, S.; Spiegelman, B.M.; Roeder, R.G. Coordination of p300-mediated chromatin re-modelling and TRAP/mediator function through coactivatorPGC-1 $\alpha$. Mol. Cell. 2003, 12, 1137-1149. [CrossRef]

32. Puigserver, P.; Adelmant, G.; Wu, Z.; Fan, M.; Xu, J.; O’Malley, B.; Spiegelman, B.M. Activation of PPAR $\gamma$ coactivator-1 through transcription factor docking. Science 1999, 286, 1368-1371. [CrossRef] [PubMed]

33. Sano, M.; Izumi, Y.; Helenius, K.; Asakura, M.; Rossi, D.J.; Xie, M.; Taffet, G.; Hu, L.; Pautler, R.G.; Wilson, C.R.; et al. Menage-àTrois 1 is critical for the transcriptional function of PPAR $\gamma$ coactivator1. Cell Metab. 2007, 5, 129-142. [CrossRef] [PubMed]

34. Viswakarma, N.; Jia, Y.; Bai, L.; Vluggens, A.; Borensztajn, J.; Xu, J.; Reddy, J.K. Coactivators in PPAR-regulated gene expression. PPAR Res. 2010, 2010, 250126. [CrossRef]

35. Kang, Z.; Fan, R. PPAR $\alpha$ and NCOR/SMRT corepressor network in liver metabolic regulation. FASEB J. 2020, 34, 8796-8809. [CrossRef]

36. Karagianni, P.; Wong, J. HDAC3: Taking the SMRT-N-CoRrect road to repression. Oncogene 2007, 26, 5439-5449. [CrossRef]

37. Oberoi, J.; Fairall, L.; Watson, P.J.; Yang, J.-C.; Czimmerer, Z.; Kampmann, T.; Goult, B.T.; Greenwood, J.A.; Gooch, J.T.; Kallenberger, B.C.; et al. Structural basis for the assembly of the SMRT/NCoR core transcriptional repression machinery. Nat. Struct. Mol. Biol. 2011, 18, 177-184. [CrossRef]

38. Compe, E.; Drane, P.; Laurent, C.; Diderich, K.; Braun, C.; Hoeijmakers, J.H.; Egly, J.M. Dysregulation of the peroxisome proliferator-activated receptor target genes by XPD mutations. Mol. Cell Biol. 2005, 25, 6065-6076. [CrossRef] [PubMed]

39. Brunmeir, R.; Xu, F. Functional regulation of PPARs through post-translational modifications. Int. J. Mol. Sci. 2018, 19, 1738. [CrossRef]

40. Hinds, T.D., Jr.; Burns, K.A.; Hosick, P.A.; McBeth, L.; Nestor-Kalinoski, A.; Drummond, H.A.; AlAmodi, A.A.; Hankins, M.W.; Vanden Heuvel, J.P.; Stec, D.E. Biliverdin reductase A attenuates hepatic steatosis by inhibition of glycogen synthase kinase (GSK) 3_ phosphorylation of serine 73 of peroxisome proliferator-activated receptor (PPAR). J. Biol. Chem. 2016, 291, 25179-25191. [CrossRef]

41. Barger, P.M.; Browning, A.C.; Garner, A.N.; Kelly, D.P. P38 mitogen-activated protein kinase activates peroxisome proliferatoractivated receptor alpha: A potential role in the cardiac metabolic stress response. J. Biol. Chem. 2001, 276, 44495-44501. [CrossRef] [PubMed]

42. Juge-Aubry, C.E.; Hammar, E.; Siegrist-Kaiser, C.; Pernin, A.; Takeshita, A.; Chin, W.W.; Burger, A.G.; Meier, C.A. Regulation of the transcriptional activity of the peroxisome proliferator-activated receptor alpha by phosphorylation of a ligand-independent trans-activating domain. J. Biol. Chem. 1999, 274, 10505-10510. [CrossRef] [PubMed]

43. Wadosky, K.M.; Willis, M.S. The story so far: Post-translational regulation of peroxisome proliferator-activated receptors by ubiquitination and SUMOylation. Am. J. Physiol. Heart Circ. Physiol. 2012, 302, H515-H526. [CrossRef]

44. Ohshima, T.; Koga, H.; Shimotohno, K. Transcriptional activity of peroxisome proliferator-activated receptor is modulated by SUMO-1 modification. J. Biol. Chem. 2004, 279, 29551-29557. [CrossRef] [PubMed]

45. Floyd, Z.E.; Stephens, J.M. Control of peroxisome proliferator-activated receptor 2 stability and activity by SUMOylation. Obes. Res. 2004, 12, 921-928. [CrossRef]

46. Leuenberger, N.; Pradervand, S.; Wahli, W. Sumoylated PPARalpha mediates sex-specific gene repression and protects the liver from estrogen-induced toxicity in mice. J. Clin. Investig. 2009, 119, 3138-3148. [CrossRef] [PubMed] 
47. Pourcet, B.; Pineda-Torra, I.; Derudas, B.; Staels, B.; Glineur, C. SUMOylation of human peroxisome proliferator-activated receptor alpha inhibits its trans-activity through the recruitment of the nuclear corepressor NCoR. J. Biol. Chem. 2010, 285, 5983-5992. [CrossRef] [PubMed]

48. Diezko, R.; Suske, G. Ligand binding reduces SUMOylation of the peroxisome proliferator-activated receptor $\gamma($ PPAR $\gamma$ ) activation function 1 (AF1) domain. PLoS ONE 2013, 8, e66947. [CrossRef]

49. Shimizu, M.; Yamashita, D.; Yamaguchi, T.; Hirose, F.; Osumi, T. Aspects of the regulatory mechanisms of PPAR functions: Analysis of a bidirectional response element and regulation by SUMOylation. Mol. Cell Biochem. 2006, 286, 33-42. [CrossRef] [PubMed]

50. Yamashita, D.; Yamaguchi, T.; Shimizu, M.; Nakata, N.; Hirose, F.; Osumi, T. The transactivating function of peroxisome proliferator-activated receptor gamma is negatively regulated by SUMO conjugation in the amino-terminal domain. Genes Cells 2004, 9, 1017-1029. [CrossRef]

51. Blanquart, C.; Barbier, O.; Fruchart, J.C.; Staels, B.; Glineur, C. Peroxisome proliferator-activated receptor alpha (PPARalpha) turnover by the ubiquitin-proteasome system controls the ligand-induced expression level of its target genes. J. Biol. Chem. 2002, 277, 37254-37259. [CrossRef] [PubMed]

52. Gopinathan, L.; Hannon, D.B.; Peters, J.M.; Vanden Heuvel, J.P. Regulation of peroxisome proliferator-activated receptor-alpha by MDM2. Toxicol. Sci. 2009, 108, 48-58. [CrossRef] [PubMed]

53. Muratani, M.; Tansey, W.P. How the ubiquitin-proteasome system controls transcription. Nat. Rev. Mol. Cell Biol. $2003,4,192-201$. [CrossRef] [PubMed]

54. Genini, D.; Catapano, C.V. Block of nuclear receptor ubiquitination. A mechanism of ligand-dependent control of peroxisome proliferator-activated receptor delta activity. J. Biol. Chem. 2007, 282, 1776-11785. [CrossRef]

55. Chen, F.; Wang, M.; O'Connor, J.P.; He, M.; Tripathi, T.; Harrison, L.E. Phosphorylation of PPAR $\gamma$ via active ERK1/2 leads to its physical association with p65 and inhibition of NF-кB. J. Cell Biochem. 2003, 90, 732-744. [CrossRef] [PubMed]

56. Delerive, P.; Gervois, P.; Fruchart, J.-C.; Staels, B. Induction of IkBa expression as a mechanism contributing to the antiinflammatory activities of PPARa activators. J. Biol. Chem. 2000, 275, 36703-36707. [CrossRef] [PubMed]

57. Schnegg, C.; Kooshki, M.; Hsu, F.-C.; Sui, G.; Robbins, M.E. PPAR $\delta$ prevents radiation-induced proinflammatory responses in microglia via transrepression of NF-kB and inhibition of the PKC $\alpha$ /MEK1/2/ERK1/2/AP-1 pathway. Free Radic. Biol. Med. 2012, 52, 1734-1743. [CrossRef]

58. Chung, S.W.; Kang, B.Y.; Kim, S.H.; Pak, Y.K.; Cho, D.; Trinchieri, G.; Kim, T.S. Oxidized low density lipoprotein inhibits interleukin-12production in lipopolysaccharide-activated mouse macrophages via direct interactions between peroxisome proliferator-activated receptor-gamma and nuclear factor-kappa B. J. Biol. Chem. 2000, 275, 32681-32687. [CrossRef]

59. Okayasu, T.; Tomizawa, A.; Suzuki, K.; Manaka, K.; Hattori, Y. PPARa activators upregulate eNOS activity and inhibit cytokineinduced NF-kB activation through AMP-activated protein kinase activation. Life Sci. 2008, 82, 884-891. [CrossRef]

60. Degang, H.; Quanlai, Z.; Hongfei, L.; Yongjie, G.; Hongguang, X. PPAR- $\alpha$ agonist WY-14643 inhibits LPS-induced inflammation in synovial fibroblasts via NF-kB pathway. J. Mol. Neuros. 2016, 59, 544-553. [CrossRef]

61. Straus, D.S.; Glass, C.K. Anti-inflammatory actions of PPAR ligands: New insights on cellular and molecular mechanisms. Trends Immunol. 2007, 28, 551-558. [CrossRef] [PubMed]

62. Haynes, R.L.; Szweda, L.; Pickin, K.; Welker, M.E.; Townsend, A.J. Structure-activity relationships for growth inhibition and induction of apoptosis by 4-hydroxy-2-nonenal in RAW 264.7 cells. Mol. Pharmacol. 2000, 58, 788-794. [CrossRef]

63. Maggiora, M.; Bologna, M.; Cerù, M.P.; Possati, L.; Angelucci, A.; Cimini, A.; Miglietta, A.; Bozzo, F.; Margiotta, C.; Muzio, G.; et al. An overview of the effect of linoleic and conjugated-linoleic acids on the growth of several human tumor cell lines. Int. J. Cancer 2004, 112, 909-919. [CrossRef]

64. Martinasso, G.; Saracino, S.; Maggiora, M.; Oraldi, M.; Canuto, R.A.; Muzio, G. Conjugated linoleic acid prevents cell growth and cytokine production induced by TPA in human keratinocytes NCTC 2544. Cancer Lett. 2010, 287, 62-66. [CrossRef]

65. Cotogni, P.; Trombetta, A.; Muzio, G.; Maggiora, M.; Canuto, R.A. The omega-3 fatty acid docosahexaenoic acid modulates inflammatory mediator release in human alveolar cells exposed to bronchoalveolar lavage fluid of ARDS patients. Biomed. Res. Int. 2015, 2015, 642520. [CrossRef] [PubMed]

66. Pascual, G.; Fong, A.L.; Ogawa, S.; Gamliel, A.; Li, A.C.; Perissi, V.; Rose, D.W.; Willson, T.M.; Rosenfeld, M.G.; Glass, C.K. A SUMOylation-dependent pathway mediates transrepression of inflammatory response genes by PPAR-gamma. Nature 2005, 437, 759-763. [CrossRef] [PubMed]

67. Zúñiga, J.; Cancino, M.; Medina, F.; Varela, P.; Vargas, R.; Tapia, G.; Videla, L.A.; Fernández, V. N-3 PUFA supplementation triggers PPAR- $\alpha$ activation and PPAR- $\alpha / N F-\kappa B$ interaction: Anti-inflammatory implications in liver ischemia-reperfusion injury. PLoS ONE 2011, 6, e28502. [CrossRef] [PubMed]

68. Kumar, N.; Gupta, G.; Anilkumar, K.; Fatima, N.; Karnati, R.; Reddy, G.V.; Giri, P.V.; Reddanna, P. 15-Lipoxygenase metabolites of $\alpha$-linolenic acid, [13-(S)-HPOTrE and 13-(S)-HOTrE], mediate anti-inflammatory effects by inactivating NLRP3 inflammasome. Sci. Rep. 2016, 6, 31649. [CrossRef] [PubMed]

69. Hu, L.; Chen, H.; Zhang, X.; Feng, Z.; Zhang, H.; Meng, Q. Rosiglitazone ameliorates radiation-induced intestinal inflammation in rats by inhibiting NLRP3 inflammasome and TNF- $\alpha$ production. J. Radiat. Res. 2020, 61, 842-850. [CrossRef] [PubMed] 
70. Haskova, Z.; Hoang, B.; Luo, G.; Morgan, L.A.; Billin, A.N.; Barone, F.C.; Shearer, B.G.; Barton, M.E.; Kilgore, K.S. Modulation of LPS-induced pulmonary neutrophil infiltration and cytokine production by the selective PPARb/d ligand GW0742. Inflamm. Res. 2008, 57, 314-321. [CrossRef]

71. Zandbergen, F.; Plutzky, J. PPARalpha in atherosclerosis and inflammation. Biochim. Biophys. Acta 2007, 1771, 972-982. [CrossRef] [PubMed]

72. Yuan, Z.; Luo, G.; Li, X.; Chen, J.; Wu, J.; Peng, Y. PPARgamma inhibits HMGB1 expression through upregulation of miR-142-3p in vitro and in vivo. Cell Signal. 2016, 28, 158-164. [CrossRef]

73. Wang, D.; Shi, L.; Xin, W.; Xu, J.; Xu, J.; Li, Q.; Xu, Z.; Wang, J.; Wang, G.; Yao, W.; et al. Activation of PPAR $\gamma$ inhibits proinflammatory cytokines production by upregulation of miR-124 in vitro and in vivo. Biochem. Biophys. Res. Commun. 2017, 486, 726-731. [CrossRef] [PubMed]

74. Wu, S.H.; Chen, X.Q.; Lü, J.; Wang, M.J. BML-111 Attenuates Renal Ischemia/Reperfusion Injury Via Peroxisome ProliferatorActivated Receptor- $\alpha$-Regulated Heme Oxygenase-1. Inflammation 2016, 39, 611-624. [CrossRef]

75. Mogilenko, D.A.; Kudriavtsev, I.V.; Shavva, V.S.; Dizhe, E.B.; Vilenskaya, E.G.; Efremov, A.M.; Perevozchikov, A.P.; Orlov, S.V. Peroxisome proliferator-activated receptor $\alpha$ positively regulates complement $\mathrm{C} 3$ expression but inhibits tumor necrosis factor $\alpha$-mediated activation of C3 gene in mammalian hepatic-derived cells. J. Biol Chem. 2013, 288, 1726-1738. [CrossRef]

76. Zenhom, M.; Hyder, A.; Kraus-Stojanowic, I.; Auinger, A.; Roeder, T.; Schrezenmeir, J. PPAR $\gamma$-dependent peptidoglycan recognition protein 3 (PGlyRP3) expression regulates proinflammatory cytokines by microbial and dietary fatty acids. Immunobiology 2011, 216, 715-724. [CrossRef] [PubMed]

77. Thompson, P.W.; Bayliffe, A.I.; Warren, A.P.; Lamb, J.R. Interleukin-10 is upregulated by nanomolar rosiglitazone treatment of mature dendritic cells and human CD4+ T cells. Cytokine 2007, 39, 184-191. [CrossRef]

78. Cho, H.Y.; Gladwell, W.; Wang, X.; Chorley, B.; Bell, D.; Reddy, S.P.; Kleeberger, S.R. Nrf2-regulated PPAR \{gamma\} expression is critical to protection against acute lung injury in mice. Am. J. Respir. Crit. Care Med. 2010, 182, 170-182. [CrossRef] [PubMed]

79. Huang, J.; Tabbi-Anneni, I.; Gunda, V.; Wang, L. Transcription factor Nrf2 regulates SHP and lipogenic gene expression in hepatic lipid metabolism. Am. J. Physiol. Gastrointest. Liver Physiol. 2010, 299, G1211-G1221. [CrossRef] [PubMed]

80. Kvandová, M.; Majzúnová, M.; Dovinová, I. The role of PPARgamma in cardiovascular diseases. Physiol. Res. 2016, 65 (Suppl. 3), S343-S363. [CrossRef]

81. Delerive, P.; De Bosscher, K.; Besnard, S.; Vanden Berghe, W.; Peters, J.M.; Gonzalez, F.J.; Fruchart, J.C.; Tedgui, A.; Haegeman, G.; Staels, B. Peroxisome proliferator-activated receptor alpha negatively regulates the vascular inflammatory gene response by negative cross-talk with transcription factors NF-kappaB and AP-1. J. Biol. Chem. 1999, 274, 32048-32054. [CrossRef]

82. Shipley, J.M.; Waxman, D.J. Down-regulation of STAT5b transcriptional activity by ligand-activated peroxisome proliferatoractivated receptor (PPAR) alpha and PPARgamma. Mol. Pharmacol. 2003, 64, 355-364. [CrossRef] [PubMed]

83. Zhou, Y.C.; Waxman, D.J. Cross-talk between Janus kinase-signal transducer and activator of transcription (JAK-STAT) and peroxisome proliferator activated receptor- (PPAR) signaling pathways. Growth hormone inhibition of PPAR transcriptional activity mediated by stat5b. J. Biol. Chem. 1999, 274, 2672-2681. [CrossRef]

84. Zhou, Y.C.; Waxman, D.J. STAT5b down-regulates peroxisome proliferator activated receptor transcription by inhibition of ligand-independent activation function region-1 trans-activation domain. J. Biol. Chem. 1999, 274, 29874-29882. [CrossRef] [PubMed]

85. Li, N.; Salter, R.C.; Ramji, D.P. Molecular mechanisms underlying the inhibition of IFN- $\gamma$-induced, STAT1-mediated gene transcription in human macrophages by simvastatin and agonists of PPARs and LXRs. J. Cell Biochem. 2011, 112, 675-683. [CrossRef]

86. Zhao, M.; Bian, Y.; Yang, L.L.; Chen, Y.-Q.; Wang, Y.-J.; Ma, Y.-T.; Pei, Y.-Q.; Li, W.-L.; Zeng, L. HuoXueTongFu formula alleviates by regulating macrophage polarization and the SOCS/JAK2/STAT/PPAR-signalling pathway. Mediat. Inflamm. 2019, 2019, 1769374. [CrossRef] [PubMed]

87. Miao, H.; Ou, J.; Ma, Y.; Guo, F.; Yang, Z.; Wiggins, M.; Liu, C.; Song, W.; Han, X.; Wang, M.; et al. Macrophage CGI-58 deficiency activates ROS-inflammasome pathway to promote insulin resistance in mice. Cell Rep. 2014, 7, 223-235. [CrossRef] [PubMed]

88. Lopez-Tenorio, I.I.; Domínguez-Lopez, A.; Miliar-García, A.; Escalona-Cardoso, G.N.; Real-Sandoval, S.A.; Gomez-Alcal, A.; Jaramillo-Flores, M.E. Modulation of the mRNA of the Nlrp3 inflammasome by Morin and PUFAs in an obesity model induced by a high-fat diet. Food Res. Int. 2020, 137, 109706. [CrossRef] [PubMed]

89. Zhao, C.-C.; Xu, J.; Xie, Q.-M.; Zhang, H.-Y.; Fei, G.-H.; Wu, H.-M. Abscisic acid suppresses the activation of NLRP3 inflammasome and oxidative stress in murine allergic airway inflammation. Phytother. Res. 2021, 35, 3298-3309. [CrossRef] [PubMed]

90. Lee, H.J.; Yeon, J.E.; Ko, E.J.; Yoon, E.L.; Suh, S.J.; Kang, K.; Kim, H.R.; Kang, S.H.; Yoo, Y.J.; Je, J.; et al. Peroxisome proliferatoractivated receptor-delta agonist ameliorated inflammasome activation in nonalcoholic fatty liver disease. World J. Gastroenterol. 2015, 21, 12787-12799. [CrossRef] [PubMed]

91. Yang, C.-C.; Wu, C.-H.; Lin, T.-C.; Cheng, Y.-N.; Chang, C.-S.; Lee, K.-T.; Tsai, P.-J.; Tsai, Y.-S. Inhibitory effect of PPARg on NLRP3 inflammasome activation. Theranostics 2021, 11, 2424-2441. [CrossRef]

92. Nguyen, T.; Nioi, P.; Pickett, C.B. The Nrf2-antioxidant response element signaling pathway and its activation by oxidative stress. J. Biol. Chem. 2009, 284, 13291-13295. [CrossRef]

93. Lushchak, V.I. Free radicals, reactive oxygen species, oxidative stress and its classification. Chem. Biol. Interact. 2014, 224, 164-175. [CrossRef] [PubMed] 
94. Lushchak, V.I.; Storey, K.B. Oxidative stress concept updated: Definitions, classifications, and regulatory pathways implicated. EXCLI J. 2021, 20, 956-967. [CrossRef]

95. Brigelius-Flohé, R.; Flohé, L. Basic principles and emerging concepts in the redox control of transcription factors. Antioxid Redox Signal. 2011, 15, 2335-2381. [CrossRef] [PubMed]

96. Bellezza, I.; Mierla, A.L.; Minelli, A. Nrf2 and NF-B and their concerted modulation in cancer pathogenesis and progression. Cancer 2010, 2, 483-497. [CrossRef] [PubMed]

97. Sandberg, M.; Patil, J.; D'Angelo, B.; Weber, S.G.; Mallard, C. NRF2-regulation in brain health and disease: Implication of cerebral inflammation. Neuropharmacology 2014, 79, 298-306. [CrossRef] [PubMed]

98. Rushworth, S.A.; Shah, S.; MacEwan, D.J. TNF mediates the sustained activation of Nrf2 in human monocytes. J. Immunol. 2011, 187, 702-707. [CrossRef]

99. Rojo, A.I.; Innamorato, N.G.; Martín-Moreno, A.M.; De Ceballos, M.L.; Yamamoto, M.; Cuadrado, A. Nrf2 regulates microglial dynamics and neuroinflammation in experimental Parkinson's disease. Glia 2010, 58, 588-598. [CrossRef] [PubMed]

100. Ho, F.M.; Kang, H.C.; Lee, S.T.; Chao, Y.; Chen, Y.C.; Huang, L.J.; Lin, W.-W. The anti-inflammatory actions of LCY-2-CHO, a carbazole analogue, in vascular smooth muscle cells. Biochem. Pharmacol. 2007, 74, 298-308. [CrossRef]

101. Park, E.Y.; Cho, I.J.; Kim, S.G. Transactivation of the PPAR-responsive enhancer module in chemopreventive glutathione Stransferase gene by the peroxisome proliferator-activated receptor-gamma and retinoid X receptor heterodimer. Cancer Res. 2004, 64, 3701-3713. [CrossRef]

102. Lee, C. Collaborative Power of Nrf2 and PPAR $\gamma$ activators against metabolic and drug-induced oxidative injury. Oxidative Med. Cell Longev. 2017, 2017, 1378175. [CrossRef]

103. Zhou, Y.Q.; Liu, D.Q.; Chen, S.P.; Chen, N.; Sun, J.; Wang, X.M.; Li, D.Y.; Tian, Y.K.; Ye, D.W. PPAR $\gamma$ activation mitigates mechanical allodynia in paclitaxel-induced neuropathic pain via induction of Nrf2/HO-1 signaling pathway. Biomed. Pharmacother. 2020, 129, 110356. [CrossRef]

104. De Nuccio, C.; Bernardo, A.; Troiano, C.; Brignone, M.S.; Falchi, M.; Greco, A.; Rosini, M.; Basagni, F.; Lanni, C.; Serafini, M.; et al. NRF2 and PPAR $-\gamma$ pathways in oligodendrocyte progenitors: Focus on ROS protection, mitochondrial biogenesis and promotion of cell differentiation. Int. J. Mol. Sci. 2020, 21, 7216. [CrossRef]

105. Okuno, Y.; Matsuda, M.; Miyata, Y.; Fukuhara, A.; Komur, R.; Shimabukuro, M.; Shimomura, I. Human catalase gene is regulated by peroxisome proliferator activated receptor-gamma through a response element distinct from that of mouse. Endocr. J. 2010, 57, 303-309. [CrossRef] [PubMed]

106. Girnun, G.D.; Domann, F.E.; Moore, S.A.; Robbins, M.E.C. Identification of a functional peroxisome proliferator-activated receptor response element in the rat catalase promoter. Mol. Endocrinol. 2002, 16, 2793-2801. [CrossRef] [PubMed]

107. Hur, J.; Kang, E.S.; Hwang, J.S.; Lee, W.J.; Won, J.P.; Lee, H.G.; Kim, E.; Seo, H.G. Peroxisome proliferator-activated receptor-deltamediated upregulation of catalase helps to reduce ultraviolet B-induced cellular injury in dermal fibroblasts. J. Dermatol Sci. 2021, 103, 167-175. [CrossRef] [PubMed]

108. Qing, L.; Weis, S.; HaoWeng, Y.; Helston, R.; Rish, K.; Smith, A.; Bordner, J.; Polte, T.; Gaunitz, F.; Dennery, P.A. Heme Oxygenase-1 Protein Localizes to the Nucleus and Activates Transcription Factors Important in Oxidative Stress. J. Biol. Chem. 2007, 282, 20621-20633. [CrossRef]

109. Vanella, L.; Barbagallo, I.; Tibullo, D.; Forte, S.; Zappalà, A.; Li Volti, G. The non-canonical functions of the heme oxygenases. Oncotarget 2016, 7, 69075-69086. [CrossRef] [PubMed]

110. Reddy, A.T.; Lakshmi, S.P.; Banno, A.; Reddy, R.C. Role of GPx3 in PPAR $\gamma$-induced protection against COPD-associated oxidative stress. Free Radic. Biol. Med. 2018, 126, 350-357. [CrossRef] [PubMed]

111. Ding, G.; Fu, M.; Qin, Q.; Lewis, W.; Kim, H.W.; Fukai, T.; Bacanamwo, M.; Chen, Y.E.; Schneider, M.D.; Mangelsdorf, D.J.; et al. Cardiac peroxisome proliferator-activated receptor gamma is essential in protecting cardiomyocytes from oxidative damage. Cardiovasc. Res. 2007, 76, 269-279. [CrossRef] [PubMed]

112. Hawkes, H.J.; Karlenius, T.C.; Tonissen, K.F. Regulation of the human thioredoxin gene promoter and its key substrates: A study of functional and putative regulatory elements. Biochim. Biophys. Acta 2014, 1840, 303-314. [CrossRef]

113. Jedidi, I.; Couturier, M.; Thérond, P.; Gardès-Albert, M.; Legrand, A.; Barouki, R.; Bonnefont-Rousselot, D.; Aggerbeck, M. Cholesteryl ester hydroperoxides increase macrophage CD36 gene expression via PPARalpha. Biochem. Biophys. Res. Commun. 2006, 351, 733-738. [CrossRef] [PubMed]

114. Teruel, T.; Clapham, J.C.; Smith, S.A. PPARalpha activation by Wy 14643 induces transactivation of the rat UCP-1 promoter without increasing UCP-1 mRNA levels and attenuates PPARgamma-mediated increases in UCP-1 mRNA levels induced by rosiglitazone in fetal rat brown adipocytes. Biochem. Biophys. Res. Commun. 1999, 264, 311-315. [CrossRef] [PubMed]

115. Teruel, T.; Smith, S.A.; Peterson, J.; Clapham, J.C. Synergistic activation of UCP-3 expression in cultured fetal rat brown adipocytes by PPARalpha and PPARgamma ligands. Biochem. Biophys. Res. Commun. 2000, 273, 560-564. [CrossRef]

116. Acín, A.; Rodriguez, M.; Rique, H.; Canet, E.; Boutin, J.A.; Galizzi, J.P. Cloning and characterization of the $5^{\prime}$ flanking region of the human uncoupling protein 3 (UCP3) gene. Biochem. Biophys. Res. Commun. 1999, 258, 278-783. [CrossRef] [PubMed]

117. Ren, Y.; Sun, C.; Sun, Y.; Tan, H.; Wu, Y.; Cui, B.; Wu, Z. PPAR gamma protects cardiomyocytes against oxidative stress and apoptosis via Bcl-2 upregulation. Vascul. Pharmacol. 2009, 51, 169-174. [CrossRef]

118. Amin, F.; Memarzia, A.; Kazemi, R.H.; Shakeri, F.; Boskabady, M.H. Systemic inflammation and oxidative stress induced by inhaled paraquat in rat improved by carvacrol, possible role of PPAR $\gamma$ receptors. Biofactors 2021, 47, 778-787. [CrossRef] 
119. Beheshti, F.; Hosseini, M.; Hashemzehi, M.; Soukhtanloo, M.; Khazaei, M.; Shafei, M.N. The effects of PPAR-gamma agonist pioglitazone on hippocampal cytokines, brain-derived neurotrophic factor, memory impairment, and oxidative stress status in lipopolysaccharide-treated rats. Iran J. Basic Med. Sci. 2019, 22, 940-948. [CrossRef]

120. Soliman, E.; Behairy, S.F.; El-Maraghy, N.N.; Elshazly, S.M. PPAR- $\gamma$ agonist, pioglitazone, reduced oxidative and endoplasmic reticulum stress associated with L-NAME-induced hypertension in rats. Life Sci. 2019, 239, 117047. [CrossRef]

121. Liu, Y.D.; Yu, S.L.; Wang, R.; Liu, J.N.; Jin, Y.S.; Li, Y.F.; An, R.H. Rosiglitazone suppresses calcium oxalate crystal binding and oxalate-induced oxidative stress in renal epithelial cells by promoting PPAR- $\gamma$ activation and subsequent regulation of TGF- $\beta 1$ and HGF. Expr. Oxid. Med. Cell Longev. 2019, 2019, 4826525. [CrossRef]

122. Yanjie, J.; Zhang, Q. Catalpol ameliorates doxorubicin-induced inflammation and oxidative stress in H9C2 cells through PPAR- $\gamma$ activation. Exp. Ther. Med. 2020, 20, 1003-1011. [CrossRef]

123. Cortes-Lopez, F.; Sanchez-Mendoza, A.; Centurion, D.; Cervantes-Perez, L.G.; Castrejon-Tellez, V.; Del Valle-Mondragon, L.; Soria-Castro, E.; Ramirez, V.; Sanchez-Lopez, A.; Pastelin-Hernandez, G.; et al. Fenofibrate protects cardiomyocytes from hypoxia/reperfusion- and high glucose-induced detrimental effects. PPAR Res. 2021, 2021, 8895376. [CrossRef]

124. Yaribeygi, H.; Mohammadi, M.T.; Jamialahmadi, T.; Sahebkar, A. PPAR-alpha agonist fenofibrate ameliorates oxidative stress in testicular tissue of diabetic rats. Crit Rev. Eukaryot Gene Expr. 2020, 30, 93-100. [CrossRef] [PubMed]

125. Papatheodorou, I.; Galatou, E.; Panagiotidis, G.D.; Ravingerová, T.; Lazou, A. Cardioprotective Effects of PPAR $\beta / \delta$ activation against ischemia/reperfusion injury in rat heart are associated with ALDH2 upregulation, amelioration of oxidative stress and preservation of mitochondrial energy production. Int. J. Mol. Sci. 2021, 22, 6399. [CrossRef]

126. Canuto, R.A.; Ferro, M.; Muzio, G.; Bassi, A.M.; Leonarduzzi, G.; Maggiora, M.; Adamo, D.; Poli, G.; Lindahl, R. Role of aldehyde metabolizing enzymes in mediating effects of aldehyde products of lipid peroxidation in liver cells. Carcinogenesis 1994, 15, 1359-1364. [CrossRef]

127. Canuto, R.A.; Ferro, M.; Salvo, R.A.; Bassi, A.M.; Trombetta, A.; Maggiora, M.; Martinasso, G.; Lindahl, R.; Muzio, G. Increase in class 2 aldehyde dehydrogenase expression by arachidonic acid in rat hepatoma cells. Biochem. J. 2001, 357, 811-818. [CrossRef]

128. Yaribeygi, H.; Mohammadi, M.T.; Sahebkar, A. PPAR- $\alpha$ agonist improves hyperglycemia-induced oxidative stress in pancreatic cells by potentiating antioxidant defense system. Drug Res. (Stuttg.) 2018, 68, 355-360. [CrossRef] [PubMed]

129. Zhang, Z.; Zhang, X.; Meng, L.; Gong, M.; Li, J.; Shi, W.; Qiu, J.; Yang, Y.; Zhao, J.; Suo, Y.; et al. Pioglitazone inhibits diabetesinduced atrial mitochondrial oxidative stress and improves mitochondrial biogenesis, dynamics, and function through the PPAR- $\gamma /$ PGC-1 $\alpha$ signaling pathway. Front. Pharmacol. 2021, 12, 658362. [CrossRef]

130. Zhang, G.; Wang, H.; Zhang, Q.; Zhao, Z.; Zhu, W.; Zuo, X. Bergenin alleviates $\mathrm{H}_{2} \mathrm{O}_{2}$-induced oxidative stress and apoptosis in nucleus pulposus cells: Involvement of the PPAR- $\gamma / \mathrm{NF}-\mathrm{kB}$ pathway. Environ. Toxicol. 2021. [CrossRef]

131. Ishola, I.O.; Tijani, H.K.; Dosumu, O.O.; Anunobi, C.C.; Oshodi, T.O. Atorvastatin attenuates testosterone-induced benign prostatic hyperplasia in rats: Role of peroxisome proliferator-activated receptor- $\gamma$ and cyclo-oxygenase-2. Fundam. Clin. Pharmacol. 2017, 31, 652-662. [CrossRef] [PubMed]

132. Ndisang, J.F. Cross-talk between heme oxygenase and peroxisome proliferator-activated receptors in the regulation of physiological functions. Front. Biosci. (Landmark Ed.) 2014, 19, 916-935. [CrossRef] [PubMed]

133. De Ciuceis, C.; Amiri, F.; Iglarz, M.; Cohn, J.S.; Touyz, R.M.; Schiffrin, E.L. Synergistic vascular protective effects of combined low doses of PPARalpha and PPARgamma activators in angiotensin II-induced hypertension in rats. Br. J. Pharmacol. 2007, 151, 45-53. [CrossRef] [PubMed]

134. Sakamoto, A.; Hongo, M.; Furuta, K.; Saito, K.; Nagai, R. and N. Ishizaka: Pioglitazone ameliorates systolic and diastolic cardiac dysfunction in rat model of angiotensin II-induced hypertension. Int. J. Cardiol. 2013, 167, 409-415. [CrossRef]

135. Li, M.; Li, Z.; Sun, X.; Yang, L.; Fang, P.; Liu, Y.; Li, W.; Xu, J.; Lu, J.; Xie, M.; et al. Heme oxygenase-1/p21WAF1 mediates peroxisome proliferator-activated receptor-gamma signaling inhibition of proliferation of rat pulmonary artery smooth muscle cells. FEBS J. 2010, 277, 1543-1550. [CrossRef]

136. Lin, H.; Yu, C.H.; Jen, C.Y.; Cheng, C.F.; Chou, Y.; Chang, C.C.; Juan, S.H. Adiponectin-mediated heme oxygenase-1 induction protects against iron-induced liver injury via a PPAR $\alpha$ dependent mechanism. Am. J. Pathol. 2010, 177, 1697-1709. [CrossRef] [PubMed]

137. Nan, Y.M.; Han, F.; Kong, L.B.; Zhao, S.X.; Wang, R.Q.; Wu, W.J.; Yu, J. Adenovirus-mediated peroxisome proliferator activated receptor gamma overexpression prevents nutritional fibrotic steatohepatitis in mice. Scand. J. Gastroenterol. 2011, 46, 358-369. [CrossRef] [PubMed]

138. Cheng, C.F.; Lian, W.S.; Chen, S.H.; Lai, P.F.; Li, H.F.; Lan, Y.F.; Cheng, W.T.; Lin, H. Protective effects of adiponectin against renal ischemia-reperfusion injury via prostacyclin-PPAR $\alpha$-heme oxygenase-1 signaling. J. Cell Physiol. 2012, 227, 239-349. [CrossRef] [PubMed]

139. Bilban, M.; Bach, F.H.; Otterbein, S.L.; Ifedigbo, E.; de Costa d'Avila, J.; Esterbauer, H.; Chin, B.Y.; Usheva, A.; Robson, S.C.; Wagner, O.; et al. Carbon monoxide orchestrates a protective response through PPAR. Immunity 2006, 24, 601-610. [CrossRef] [PubMed]

140. Woo, C.H.; Massett, M.P.; Shishido, T.; Itoh, S.; Ding, B.; McClain, C.; Che, W.; Vulapalli, S.R.; Yan, C.; Abe, J. ERK5 activation inhibits inflammatory responses via peroxisome proliferator-activated receptor delta (PPARdelta) stimulation. J. Biol. Chem. 2006, 281, 32164-32174. [CrossRef] 
141. Bilban, M.; Haslinger, P.; Prast, J.; Klinglmüller, F.; Woelfel, T.; Haider, S.; Sachs, A.; Otterbein, L.E.; Desoye, G.; Hiden, U.; et al. Identification of novel trophoblast invasion-related genes: Heme oxygenase-1 controls motility via peroxisome proliferatoractivated receptor gamma. Endocrinology 2009, 150, 1000-1013. [CrossRef]

142. Hoetzel, A.; Dolinay, T.; Vallbracht, S.; Zhang, Y.; Kim, H.P.; Ifedigbo, E.; Alber, S.; Kaynar, A.M.; Schmidt, R.; Ryter, S.W.; et al. Carbon monoxide protects against ventilator-induced lung injury via PPAR-gamma and inhibition of Egr-1. Am. J. Respir Crit. Care Med. 2008, 177, 1223-1232. [CrossRef]

143. Demine, S.; Renard, P.; Arnould, T. Mitochondrial uncoupling: A Key controller of biological processes in physiology and diseases. Cells 2019, 8, 795. [CrossRef] [PubMed]

144. Teruel, T.; Hernandez, R.; Rial, E.; Martin-Hidalgo, A.; Lorenzo, M. Rosiglitazone up-regulates lipoprotein lipase, hormonesensitive lipase and uncoupling protein-1, and down-regulates insulin-induced fatty acid synthase gene expression in brown adipocytes of Wistar rats. Diabetologia 2005, 48, 1180-1188. [CrossRef]

145. Chan, S.H.H.; Wu, K.L.H.; Kung, P.S.S.; Chan, J.Y.H. Oral intake of rosiglitazone promotes a central antihypertensive effect via upregulation of peroxisome proliferator-activated receptor-gamma and alleviation of oxidative stress in rostral ventrolateral medulla of spontaneously hypertensive rats. Hypertension 2010, 55, 1444-1453. [CrossRef] [PubMed]

146. Toral, M.; Romero, M.; Jiménez, R.; Robles-Vera, I.; Tamargo, J.; Martínez, M.C.; Pérez-Vizcaíno, F.; Duarte, J. Role of UCP2 in the protective effects of PPAR $\beta / \delta$ activation on lipopolysaccharide-induced endothelial dysfunction. Biochem. Pharmacol. 2016, 110-111, 25-36. [CrossRef]

147. Corton, J.C.; Jeffrey, M.P.; Klaunig, J.E. The PPAR $\alpha$-dependent rodent liver tumor response is not relevant to humans: Addressing misconceptions. Arch. Toxicol. 2018, 92, 83-119. [CrossRef] [PubMed]

148. Foreman, J.E.; Koga, T.; Kosyk, O.; Kang, B.H.; Zhu, X.; Cohen, S.M.; Billy, L.J.; Sharma, A.K.; Amin, S.; Gonzalez, F.J.; et al. Species Differences between mouse and human ppar $\alpha$ in modulating the hepatocarcinogenic effects of perinatal exposure to a high-affinity human PPAR $\alpha$ agonist in mice. Toxicol. Sci. 2021, 183, 81-92. [CrossRef] [PubMed]

149. Urbanek-Olejnik, K.; Liszewska, M.; Winczura, A.; Kostka, G. Changes of c-Myc and DNMT1 mRNA and protein levels in the rat livers induced by dibutyl phthalate treatment. Toxicol. Ind. Health 2016, 32, 801-808. [CrossRef]

150. Becuwe, P.; Dauça, M. Comparison of cytotoxicity induced by hypolipidemic drugs via reactive oxygen species in human and rodent liver cells. Int. J. Mol. Med. 2005, 16, 483-492. [CrossRef] [PubMed]

151. Rusyn, I.; Yamashina, S.; Segal, B.H.; Schoonhoven, R.; Holland, S.M.; Cattley, R.C.; Swenberg, J.A.; Thurman, R.G. Oxidants from nicotinamide adenine dinucleotide phosphate oxidase are involved in triggering cell proliferation in the liver due to peroxisome proliferators. Cancer Res. 2000, 60, 4798-4803. [PubMed]

152. Woods, C.G.; Kosyk, O.; Bradford, B.U.; Ross, P.K.; Burns, A.M.; Cunningham, M.L.; Qu, P.; Ibrahim, J.G.; Rusyn, I. Time course investigation of PPARalpha- and Kupffer cell-dependent effects of WY-14,643 in mouse liver using microarray gene expression. Toxicol. Appl. Pharmacol. 2007, 225, 267-277. [CrossRef] [PubMed]

153. Wang, L.; Zhao, F.; Kan, M.; Wen, Z.; Zhou, Y.; Yu, L.; Liu, H. Effects of perfluorooctanoic acid on oxidative stress and PPAR $\alpha$ and its related CYP4A1 gene expression in rat liver. Wei Sheng Yan Jiu 2017, 46, 802-806.

154. Misra, P.; Reddy, J.K. Peroxisome proliferator-activated receptor- $\alpha$ activation and excess energy burning in hepatocarcinogenesis. Biochimie 2014, 98, 63-74. [CrossRef]

155. Palmer, C.N.; Hsu, M.H.; Griffin, K.J.; Raucy, J.L.; Johnson, E.F. Peroxisome proliferator activated receptor-alpha expression in human liver. Mol. Pharmacol. 1998, 53, 14-22. [CrossRef]

156. Rakhshandehroo, M.; Hooiveld, G.; Müller, M.; Kersten, S. Comparative analysis of gene regulation by the transcription factor PPARalpha between mouse and human. PLoS ONE 2009, 4, e6796. [CrossRef]

157. Ogino, S.; Shima, K.; Baba, Y.; Nosho, K.; Irahara, N.; Kure, S.; Chen, L.; Toyoda, S.; Kirkner, G.J.; Wang, Y.L.; et al. Colorectal cancer expression of peroxisome proliferator-activated receptor gamma (PPARG, PPARgamma) is associated with good prognosis. Gastroenterology 2009, 136, 1242-1250. [CrossRef] [PubMed]

158. Lecarpentier, Y.; Claes, V.; Vallée, A.; Hébert, J.L. Interactions between PPAR Gamma and the canonical Wnt/Beta-catenin pathway in Type 2 diabetes and colon cancer. PPAR Res. 2017, 2017, 5879090. [CrossRef]

159. He, Q.; Chen, J.; Lin, H.L.; Hu, P.J.; Chen, M.H. Expression of peroxisome proliferator-activated receptor gamma, E-cadherin and matrix metalloproteinases-2 in gastric carcinoma and lymph node metastases. Chin. Med. J. (Engl.) 2007, 120, 1498-1504. [CrossRef] [PubMed]

160. Aldred, M.A.; Morrison, C.; Gimm, O.; Hoang-Vu, C.; Krause, U.; Dralle, H.; Jhiang, S.; Eng, C. Peroxisome proliferator-activated receptor gamma is frequently downregulated in a diversity of sporadic nonmedullary thyroid carcinomas. Oncogene 2003, 22, 3412-3416. [CrossRef] [PubMed]

161. Jung, T.I.; Baek, W.K.; Suh, S.I.; Jang, B.C.; Song, D.K.; Bae, J.H.; Kwon, K.Y.; Bae, J.H.; Cha, S.D.; Bae, I.; et al. Down-regulation of peroxisome proliferator-activated receptor gamma in human cervical carcinoma. Gynecol. Oncol. 2005, 97, 365-373. [CrossRef] [PubMed]

162. Terashita, Y.; Sasaki, H.; Haruki, N.; Nishiwaki, T.; Ishiguro, H.; Shibata, Y.; Kudo, J.; Konishi, S.; Kato, J.; Koyama, H.; et al. Decreased peroxisome proliferator-activated receptor gamma gene expression is correlated with poor prognosis in patients with esophageal cancer. Jpn. J. Clin. Oncol. 2002, 32, 238-243. [CrossRef] 
163. Rogenhofer, S.; Ellinger, J.; Kahl, P.; Stoehr, C.; Hartmann, A.; Engehausen, D.; Wieland, W.F.; Müller, S.C.; Hofstädter, F.; Walter, B. Enhanced expression of Peroxisome Proliferate-activated Receptor Gamma (PPAR- $\gamma$ ) in advanced prostate cancer. Anticancer Res. 2012, 32, 3479-3484.

164. Yaghoubizadeh, M.; Pishkar, L.; Basati, G. Aberrant expression of Peroxisome Proliferator-Activated Receptors in colorectal cancer and their association with cancer progression and prognosis. Gastrointest. Tumors 2020, 7, 11-20. [CrossRef]

165. Morinishi, T.; Tokuhara, Y.; Ohsaki, H.; Ibuki, E.; Kadota, K.; Hirakawa, E. Activation and expression of Peroxisome ProliferatorActivated Receptor Alpha are associated with tumorigenesis in colorectal carcinoma. PPAR Res. 2019, 2019, 7486727. [CrossRef]

166. Wang, C.Y.; Chao, Y.J.; Chen, Y.L.; Wang, T.W.; Phan, N.N.; Hsu, H.P.; Shan, Y.S.; Lai, M.D. Upregulation of peroxisome proliferator-activated receptor- $\alpha$ and the lipid metabolism pathway promotes carcinogenesis of ampullary cancer. Int. J. Med. Sci. 2021, 18, 256-269. [CrossRef] [PubMed]

167. Li, X.; Lu, Y.; Ou, X.; Zeng, S.; Wang, Y.; Qi, X.; Zhu, L.; Liu, Z. Changes and sex- and age-related differences in the expression of drug metabolizing enzymes in a KRAS-mutant mouse model of lung cancer. PeerJ 2020, 8, e10182. [CrossRef]

168. Martín-Martín, N.; Zabala-Letona, A.; Fernández-Ruiz, S.; Arreal, L.; Camacho, L.; Castillo-Martin, M.; Cortazar, A.R.; Torrano, V.; Astobiza, I.; Zúñiga-García, P.; et al. PPAR elicits ligand-independent repression of Trefoil factor family to limit prostate cancer growth. Cancer Res. 2018, 78, 399-409. [CrossRef]

169. Michiels, J.F.; Perrin, C.; Leccia, N.; Massi, D.; Grimaldi, P.; Wagner, N. PPARbeta activation inhibits melanoma cell proliferation involving repression of the Wilms' tumour suppressor WT1. Pflug. Arch. 2010, 459, 689-703. [CrossRef] [PubMed]

170. Genini, D.; Garcia-Escudero, R.; Carbone, G.M.; Catapano, C.V. Transcriptional and Non-Transcriptional Functions of PPAR $\beta / \delta$ in Non-Small Cell Lung Cancer. PLoS ONE 2012, 7, e46009. [CrossRef] [PubMed]

171. Zeng, L.; Geng, Y.; Tretiakova, M.; Yu, X.; Sicinski, P.; Kroll, T.G. Peroxisome proliferator-activated receptor-delta induces cell proliferation by a cyclin E1-dependent mechanism and is up-regulated in thyroid tumors. Cancer Res. 2008, 68, 6578-6586. [CrossRef]

172. Daikoku, T.; Tranguch, S.; Chakrabarty, A.; Wang, D.; Khabele, D.; Orsulic, S.; Morrow, J.D.; Dubois, R.N.; Dey, S.K. Extracellular signal-regulated kinase is a target of cyclooxygenase-1-peroxisome proliferator-activated receptor-delta signaling in epithelial ovarian cancer. Cancer Res. 2007, 67, 5285-5292. [CrossRef] [PubMed]

173. Maggiora, M.; Oraldi, M.; Muzio, G.; Canuto, R.A. Involvement of PPAR $\alpha$ and PPAR $\gamma$ in apoptosis and proliferation of human hepatocarcinoma HepG2 cells. Cell Biochem. Funct. 2010, 28, 571-577. [CrossRef] [PubMed]

174. Muzio, G.; Maggiora, M.; Trombetta, A.; Martinasso, G.; Reffo, P.; Colombatto, S.; Canuto, R.A. Mechanisms involved in growth inhibition induced by clofibrate in hepatoma cells. Toxicology 2003, 187, 149-159. [CrossRef]

175. Muzio, G.; Maggiora, M.; Oraldi, M.; Trombetta, A.; Canuto, R.A. PPARalpha and PP2A are involved in the proapoptotic effect of conjugated linoleic acid on human hepatoma cell line SK-HEP-1. Int. J. Cancer 2007, 121, 2395-2401. [CrossRef]

176. Cerbone, A.; Toaldo, C.; Pizzimenti, S.; Pettazzoni, P.; Dianzani, C.; Minelli, R.; Ciamporcero, E.; Roma, G.; Dianzani, M.U.; Canaparo, R.; et al. AS601245, an anti-Inflammatory JNK inhibitor, and clofibrate have a synergistic effect in inducing cell responses and in affecting the gene expression profile in CaCo-2 colon cancer cells. PPAR Res. 2012, 2012, 269751. [CrossRef] [PubMed]

177. Pizzimenti, S.; Laurora, S.; Briatore, F.; Ferretti, C.; Dianzani, M.U.; Barrera, G. Synergistic effect of 4-hydroxynonenal and PPAR ligands in controlling human leukemic cell growth and differentiation. Free Radic. Biol. Med. 2002, 32, 233-245. [CrossRef]

178. Cerbone, A.; Toaldo, C.; Laurora, S.; Briatore, F.; Pizzimenti, S.; Dianzani, M.U.; Ferretti, C.; Barrera, G. 4-Hydroxynonenal and PPARgamma ligands affect proliferation, differentiation, and apoptosis in colon cancer cells. Free Radic. Biol. Med. 2007, 42, 1661-1670. [CrossRef]

179. Wu, Y.W.; Zhou, X.Y.; Cai, Q.; Hu, Z.; Mi, T.G.; Zhang, B.; Zhao, L.; Lu, Q. Anticancer effect of rosiglitazone, a PPAR- $\gamma$ agonist against Diethylnitrosamine-induced lung carcinogenesis. ACS Omega 2020, 5, 5334-5339. [CrossRef] [PubMed]

180. Balupillai, A.; Prasad, R.N.; Ramasamy, K.; Muthusamy, G.; Shanmugham, M.; Govindasamy, K.; Gunaseelan, S. Caffeic acid inhibits UVB-induced inflammation and photocarcinogenesis through activation of Peroxisome Proliferator-activated Receptor- $\gamma$ in mouse skin. Photochem. Photobiol. 2015, 91, 1458-1468. [CrossRef]

181. Ngoc, N.B.; Lv, P.; Zhao, W.E. Suppressive effects of lycopene and beta-carotene on the viability of the human esophageal squamous carcinoma cell line EC109. Oncol. Lett. 2018, 15, 6727-6732. [CrossRef] [PubMed]

182. Cui, L.; Xu, F.; Wu, K.; Li, L.; Qiao, T.; Li, Z.; Chen, T.; Sun, C. Anticancer effects and possible mechanisms of lycopene intervention on N-methylbenzylnitrosamine induced esophageal cancer in F344 rats based on PPAR $\gamma$ 1. Eur. J. Pharmacol. 2020, 881, 173230. [CrossRef]

183. Fazio, V.M.; Rinaldi, M.; Ciafrè, S.; Barrera, G.; Farace, M.G. Control of neoplastic cell proliferation and differentiation by restoration of 4-hydroxynonenal physiological concentrations. Mol. Aspects Med. 1993, 14, 217-228. [CrossRef]

184. Muzio, G.; Trombetta, A.; Maggiora, M.; Martinasso, G.; Vasiliou, V.; Lassen, N.; Canuto, R.A. Arachidonic acid suppresses growth of human lung tumor A549 cells through down-regulation of ALDH3A1 expression. Free Radic. Biol. Med. 2006, 40, 1929-1938. [CrossRef]

185. Muzio, G.; Ricci, M.; Traverso, N.; Monacelli, F.; Oraldi, M.; Maggiora, M.; Canuto, R.A. 4-Hydroxyhexenal and 4-hydroxynonenal are mediators of the anti-cachectic effect of $\mathrm{n}-3$ and $\mathrm{n}-6$ polyunsaturated fatty acids on human lung cancer cells. Free Radic. Biol. Med. 2016, 99, 63-70. [CrossRef] 
186. Canuto, R.A.; Biocca, M.E.; Muzio, G.; Dianzani, M.U. Fatty acid composition of phospholipids in mitochondria and microsomes during diethylnitrosamine carcinogenesis in rat liver. Cell Biochem. Funct. 1989, 7, 11-19. [CrossRef] [PubMed]

187. Oraldi, M.; Trombetta, A.; Biasi, F.; Canuto, R.A.; Maggiora, M.; Muzio, G. Decreased polyunsaturated Fatty Acid content contributes to increased survival in human colon cancer. J. Oncol. 2009, 2009, 867915. [CrossRef]

188. Srivastava, N.; Kollipara, R.K.; Singh, D.K.; Sudderth, J.; Hu, Z.; Nguyen, H.; Wang, S.; Humphries, C.G.; Carstens, R.; Huffman, K.E.; et al. Inhibition of cancer cell proliferation by PPAR $\gamma$ is mediated by a metabolic switch that increases reactive oxygen species levels. Cell Metab. 2014, 20, 650-661. [CrossRef] [PubMed]

189. Savic, D.; Ramaker, R.C.; Roberts, B.S.; Dean, E.C.; Burwell, T.C.; Meadows, S.K.; Cooper, S.J.; Garabedian, M.J.; Gertz, J.; Myers, R.M. Distinct gene regulatory programs define the inhibitory effects of liver $\mathrm{X}$ receptors and PPARG on cancer cell proliferation Genome Med. 2016, 8, 74. [CrossRef] [PubMed]

190. Szychowski, K.A.; Leja, M.L.; Kaminskyy, D.V.; Kryshchyshyn, A.P.; Binduga, U.E.; Pinyazhko, O.R.; Lesyk, R.B.; Tobiasz, J.; Gmiński, J. Anticancer properties of 4-thiazolidinone derivatives depend on peroxisome proliferator-activated receptor gamma (PPARgamma). Eur. J. Med. Chem. 2017, 141, 162-168. [CrossRef] [PubMed]

191. Canuto, R.A.; Maggiora, M.; Trombetta, A.; Martinasso, G.; Muzio, G. Aldehyde dehydrogenase 3 expression is decreased by clofibrate via PPAR gamma induction in JM2 rat hepatoma cell line. Chem. Biol. Interact. 2003, 143-144, 29-35. [CrossRef]

192. Ricci, M.; Miola, M.; Multari, C.; Borroni, E.; Canuto, R.A.; Congiusta, N.; Vernè, E.; Follenzi, A.; Muzio, G. PPARs are mediators of anti-cancer properties of superparamagnetic iron oxide nanoparticles (SPIONs) functionalized with conjugated linoleic acid. Chem. Biol. Interact. 2018, 292, 9-14. [CrossRef] [PubMed]

193. Sladek, N.E.; Dockham, P.A.; Lee, M.O. Human and mouse hepatic aldehyde dehydrogenases important in the biotransformation of cyclophosphamide and the retinoids. Adv. Exp. Med. Biol. 1991, 284, 97-104. [CrossRef]

194. Muzio, G.; Maggiora, M.; Paiuzzi, E.; Oraldi, M.; Canuto, R.A. Aldehyde dehydrogenases and cell proliferation. Free Radic. Biol. Med. 2012, 52, 735-746. [CrossRef] [PubMed]

195. Ding, L.; Chen, X.P.; Zhang, Z.W.; Guan, J.; Zhang, W.G.; Wang, H.P.; Wang, Z.H.; Li, C.L. Synergistic effect of bromocriptine and tumor necrosis factor- $\alpha$ on reversing hepatocellular carcinoma multidrug resistance in nude mouse MDR1 model of liver neoplasm. World J. Gastroenterol. 2005, 11, 5621-5626. [CrossRef] [PubMed]

196. Matsunaga, T.; Suzuki, A.; Kezuka, C.; Okumura, N.; Iguchi, K.; Inoue, I.; Soda, M.; Endo, S.; El-Kabbani, O.; Hara, A.; et al. Aldo-keto reductase 1B10 promotes development of cisplatin resistance in gastrointestinal cancer cells through downregulatingperoxisome proliferator-activated receptor-g-dependent mechanism. Chem. Biol. Interact. 2016, 256, 142-153. [CrossRef]

197. Han, S.; Lv, X.; Wang, Y.; Gong, H.; Zhang, C.; Tong, A.; Zhang, B.; Yao, H. Effect and mechanism of peroxisome proliferatoractivated receptor- $\gamma$ on the drug resistance of the U-87 MG/CDDP human malignant glioma cell line. Mol. Med. Rep. 2015, 12, 2239-2246. [CrossRef]

198. Wang, M.; Li, G.; Yang, Z.; Wang, L.; Zhang, L.; Wang, T.; Zhang, Y.; Zhang, S.; Han, Y.; Jia, L. Uncoupling protein 2 downregulation by hypoxia through repression of peroxisome proliferator-activated receptor $\gamma$ promotes chemoresistance of non-small cell lung cancer. Oncotarget 2017, 8, 8083-8094. [CrossRef] [PubMed]

199. Kim, T.W.; Hong, D.W.; Hong, S.H. CB13, a novel PPAR $\gamma$ ligand, overcomes radio-resistance via ROS generation and ER stress in human non-small cell lung cancer. Cell Death Dis. 2020, 11, 848. [CrossRef]

200. Hayes, J.D.; McMahon, M. NRF2 and KEAP1 mutations: Permanent activation of an adaptive response in cancer. Trends Biochem. Sci. 2009, 34, 176-188. [CrossRef] [PubMed]

201. Zhan, L.; Zhang, H.; Zhang, Q.; Woods, C.G.; Chen, Y.; Xue, P.; Dong, J.; Tokar, E.J.; Xu, Y.; Hou, Y.; et al. Regulatory role of KEAP1 and NRF2 in PPAR $\gamma$ expression and chemoresistance in human non-small-cell lung carcinoma cells. Free Radic. Biol. Med. 2012, 53, 758-768. [CrossRef] [PubMed] 